Review

\title{
Evolution of Marine Organisms under Climate Change at Different Levels of Biological Organisation
}

\author{
Ben P. Harvey ${ }^{1, *}$, Balsam Al-Janabi ${ }^{2}$, Stefanie Broszeit ${ }^{3,4}$, Rebekah Cioffi ${ }^{5,6}$, \\ Amit Kumar ${ }^{7}$, Maria Aranguren-Gassis ${ }^{8}$, Allison Bailey ${ }^{9}$, Leon Green ${ }^{10}$, \\ Carina M. Gsottbauer ${ }^{11}$, Emilie F. Hall ${ }^{12}$, Maria Lechler ${ }^{13}$, Francesco P. Mancuso ${ }^{3}$, \\ Camila O. Pereira ${ }^{14}$, Elena Ricevuto ${ }^{7}$, Julie B. Schram ${ }^{15}$, Laura S. Stapp ${ }^{16}$, \\ Simon Stenberg ${ }^{17}$ and Lindzai T. Santa Rosa ${ }^{18}$
}

1 Institute of Biological, Environmental and Rural Sciences, Aberystwyth University, Aberystwyth, SY23 3DA, UK

2 GEOMAR, Helmholtz Centre for Ocean Research, Duesternbrookerweg 20, Kiel 24105, Germany; E-Mail: baljanabi@geomar.de

3 Scienze Ambientali, Università di Bologna, Via S. Alberto 163, Ravenna I-48100, Italy; E-Mails: stefbroszeit@gmail.com (S.B.); francesco.mancuso4@unibo.it (F.P.M.)

4 Plymouth Marine Laboratory, Prospect Place, The Hoe, Plymouth, PL1 3DH, UK

5 School of Biological Sciences, Plymouth University, Drake Circus, Plymouth, PL4 8AA, UK; E-Mail: rebekah.cioffi@plymouth.ac.uk

6 Marine Biology and Ecology Research Centre, School of Marine Science and Engineering, Plymouth University, Plymouth, PL4 8AA, UK

7 Stazione Zoologica “Anton Dohrn”, Punta San Pietro, Ischia (NA) 80077, Italy;

E-Mails: amit.kumar@szn.it (A.K.); elena.ricevuto@szn.it (E.R.)

8 Ecology and Animal Biology Department, University of Vigo, Campus Lagoas Marcosende, Vigo 36210, Spain; E-Mail: aranguren@uvigo.es

9 Norwegian Polar Institute, Fram Centre, Tromsø NO-9296, Norway; E-Mail: allison.bailey@npolar.no

10 Department of Biological and Environmental Sciences, University of Gothenburg, Gothenburg 405 30, Sweden; E-Mail: leon.green@hotmail.com

11 School of Biological Sciences, Queen's University Belfast, Belfast, BT9 7BL, UK; E-Mail: cgsottbauer01@qub.ac.uk

12 Marine Biology and Ecology Research Centre, School of Marine Science and Engineering, Plymouth University, Plymouth, PL4 8AA, UK; E-Mail: emilie.hall@plymouth.ac.uk

13 Dipartimento di Scienze, Università degli Studi della Basilicata, Via dell'Ateneo Lucano 10, Potenza 85100, Italy; E-Mail: maria.lechler@googlemail.com

14 Instituto Oceanográfico da Universidade de São Paulo, Praça do Oceanográfico, 191, Sala 139, Cidade Universitária, São Paulo 05508-120, Brazil; E-Mail: copereira@usp.br 
15 Department of Biology, University of Alabama at Birmingham, Birmingham, AL 35294-1170, USA; E-Mail: jbschram@uab.edu

16 Alfred Wegener Institute, Helmholtz Centre for Polar and Marine Research, Integrative Ecophysiology, Postfach 120161, D-27570 Bremerhaven, Germany; E-Mail: laura.stapp@awi.de

17 Department of Animal and Aquacultural Sciences, Norwegian University of Life Sciences (NMBU), PO Box 5003, Ås 1432, Norway; E-Mail: simon.stenberg@nmbu.no

18 School of Biological Sciences, University of Essex, Essex, CO4 3SQ, UK; E-Mail: 1torre@essex.ac.uk

* Author to whom correspondence should be addressed; E-Mail: beh14@aber.ac.uk; Tel.: +44-(0)-1970-623-111 (ext. 4187).

External Editor: Sam Dupont

Received: 4 March 2014; in revised form: 9 October 2014 / Accepted: 12 November 2014 / Published: 21 November 2014

\begin{abstract}
Research to date has suggested that both individual marine species and ecological processes are expected to exhibit diverse responses to the environmental effects of climate change. Evolutionary responses can occur on rapid (ecological) timescales, and yet studies typically do not consider the role that adaptive evolution will play in modulating biological responses to climate change. Investigations into such responses have typically been focused at particular biological levels (e.g., cellular, population, community), often lacking interactions among levels. Since all levels of biological organisation are sensitive to global climate change, there is a need to elucidate how different processes and hierarchical interactions will influence species fitness. Therefore, predicting the responses of communities and populations to global change will require multidisciplinary efforts across multiple levels of hierarchy, from the genetic and cellular to communities and ecosystems. Eventually, this may allow us to establish the role that acclimatisation and adaptation will play in determining marine community structures in future scenarios.
\end{abstract}

Keywords: ocean acidification; climate change; acclimation; evolutionary potential; adaptation; biological organisation; biologically-relevant scales

\title{
1. Introduction
}

Evolutionary processes play a fundamental role in the organisational structure of biological systems and the diversity of life [1]. It is possible for evolution to occur on a rapid ecological timescale, that may allow organisms to avoid extinction following environmental change [2]. One environment which is arguably changing faster than others is the marine environment [3], where increasing levels of atmospheric $\mathrm{CO}_{2}$ are causing the seawater temperature and carbonate chemistry of surface waters to 
change at geologically unprecedented rates [4]. Future warming and altered ocean chemistry (broadly termed climate change throughout the present review) are recognised as pervasive and detrimental anthropogenic influences on marine life [5-9]. Climate change is expected to impose strong selection pressure on fitness-related traits, impacting on populations and ecosystems [10-14], and yet most future projections of community dynamics and population persistence in marine organisms do not consider the role of evolution and adaptive capacity [15-17].

The potential for genetic adaptation in response to climate change has been acknowledged $[17,18]$, and adaptive evolution may represent a critical mechanism which could alleviate some of the negative consequences expected with future climate change [19]. However, the relatively limited number of studies means that evidence is still somewhat scarce [20]. A number of recent reviews outline the role of adaptive evolution in the face of climate change, including the need for determining species' capacity for evolutionary adaptation and physiological acclimatisation, the distinctions between evolutionary and phenotypically plastic responses, and summaries of the different experimental approaches (e.g., molecular tools, quantitative genetics, standing genetic variation, and experimental evolution). They also outline possible directions for future research (for reviews, see [16,17,19-23], and references therein). A glossary for some of the terms commonly used in this review is given in Box 1.

Box 1. Glossary for terms used in this article.

Acclimation: Reversible process of an organism to adjust to experimental conditions. When the process is induced by natural environmental changes, it is called acclimatisation.

Bottleneck effect: Reduction in population size due to environmental events, leading to a strong reduction of the variation in the gene pool.

Effective population size: Size of a hypothetical ideal population with random mating that corresponds to population genetic processes within the focal wild population.

Epigenetics: Heritable changes in gene regulation processes that are not caused by changes in the DNA sequence.

Evolution: Genetic changes in a population over generations. It is said to be microevolution when these changes occur over relatively short timescales, rather than on geological scales (macroevolution).

Evolutionary rescue: Genetic adaptation of populations that allows them to recover from demographic effects and avoid extinction.

Experimental evolution: Controlled experiment that exposes populations to new environmental conditions for multiple generations to observe for genetic adaptation.

Fitness: The potential for individuals of a given genotype to survive and pass their genes to future generations by influencing either their own reproductive success or that of related individuals.

Genetic adaptation: A process of transgenerational selection of genes to maximise or maintain the relative fitness of a population in a given environment.

Phenotypic buffering: Type of phenotypic plasticity, in which no difference in the response of a trait to a given environment might be observed because plasticity in a physiological process allows an organism to maintain fitness.

Phenotypic plasticity: Phenotypic adjustment to the environment without any genetic change.

Quantitative genetics: Method to partition the observed phenotypic variance among relatives (of known genetic relatedness) into their environmental and genetic components.

Selection: Non-random reproduction or survival of individuals of a particular phenotype. 
Studies investigating biological responses to climate change will often be carried out with a particular focus, whether that be physiology, evolutionary biology or community ecology. Such focus naturally means that other interacting facets of eco-evolution are often neglected [24]. Clearly, there are many important inter-disciplinary studies that do bridge this gap (e.g., [25-27]), however, there are still often disparities in the extent (if at all) that adaptive evolution is considered by different disciplines when determining a species' response under a changing environment. Inter-disciplinary work that links ecoevolution through biological hierarchies is not a new concept having been raised by numerous influential comparative physiologists in the 1950s, such as C. Ladd Prosser [28]. We believe this idea bears reiterating, and consider modern science to possess the necessary advancements in technology and communication required to begin incorporating this concept into future research.

There are a number of factors that mediate evolutionary processes, but their effects are highly dependent on the level of biological organisation that is considered (e.g., intra-individual, whole-organism, population, community and ecosystem, see Figure 1). The underlying mechanisms of how these levels of hierarchy will interact to influence fitness in the face of climate change are poorly understood, but are important in determining whether individual populations and communities will persist at levels comparable to the present day [16].

This review will focus on factors that can modulate adaptive evolution at different levels of biological organisation, by considering the response of marine organisms at these different levels in terms of the consequences for fitness traits (i.e., lifetime reproductive success). We discuss: (1) what molecular and cellular mechanisms exist that can influence fitness and drive adaptive evolution; (2) how changes in life history and behavioural characteristics of organisms can influence lifetime reproductive success; (3) how demographic processes (gene frequencies, population size and turnover) and genetic architecture (heritability, imprinting, genetic correlations and diversity) of the population will influence adaptive evolution; and (4) how changes in species interactions and community composition influence the magnitude and direction of adaptive evolution of populations.

\section{Role of Molecular and Cellular Processes in Evolutionary Responses}

Molecular and cellular level studies can provide several approaches for improving our understanding of the potential for adaptation in response to climate change. These can include characterising an organism's capacity to acclimatise to changing environmental conditions, as well as establishing a more mechanistic understanding of the response of organisms to abiotic factors at different levels of intraindividual biological organisation, such as the nature of sub-lethal cellular stress [29]. Eventually this might enable us to investigate whether genetic adaptation can occur at a sufficient rate to maintain the physiological functioning required for survival and reproduction, and gain important insights into energy allocation and physiological responses due to climate change, as well as other biotic and abiotic stressors [22]. However, the distribution of a species is shaped by both a species' physiological limits and biotic interactions with co-existing species, and therefore, cellular and molecular studies alone may only provide part of the picture. 
Figure 1. Conceptual diagram of the factors modulating evolution at different levels of biological organisation (molecular, cellular, whole-organism, population and community), that will determine the response of marine organisms to future climate change. The arrow on the left represents the increased biological complexity (going from top to bottom). Single-headed arrows indicate the direction of the effect with the level of biological organisation indicated by different colours. Effects originating from the molecular and cellular (dashed blue), whole-organism (dashed purple), population (dashed green) and community (dashed orange). Double-headed arrows indicate that there is feedback between two factors, as well as the effect, and the solid grey arrows indicate a feedback loop. Note that the depiction of factors is conceptual and not comprehensive.

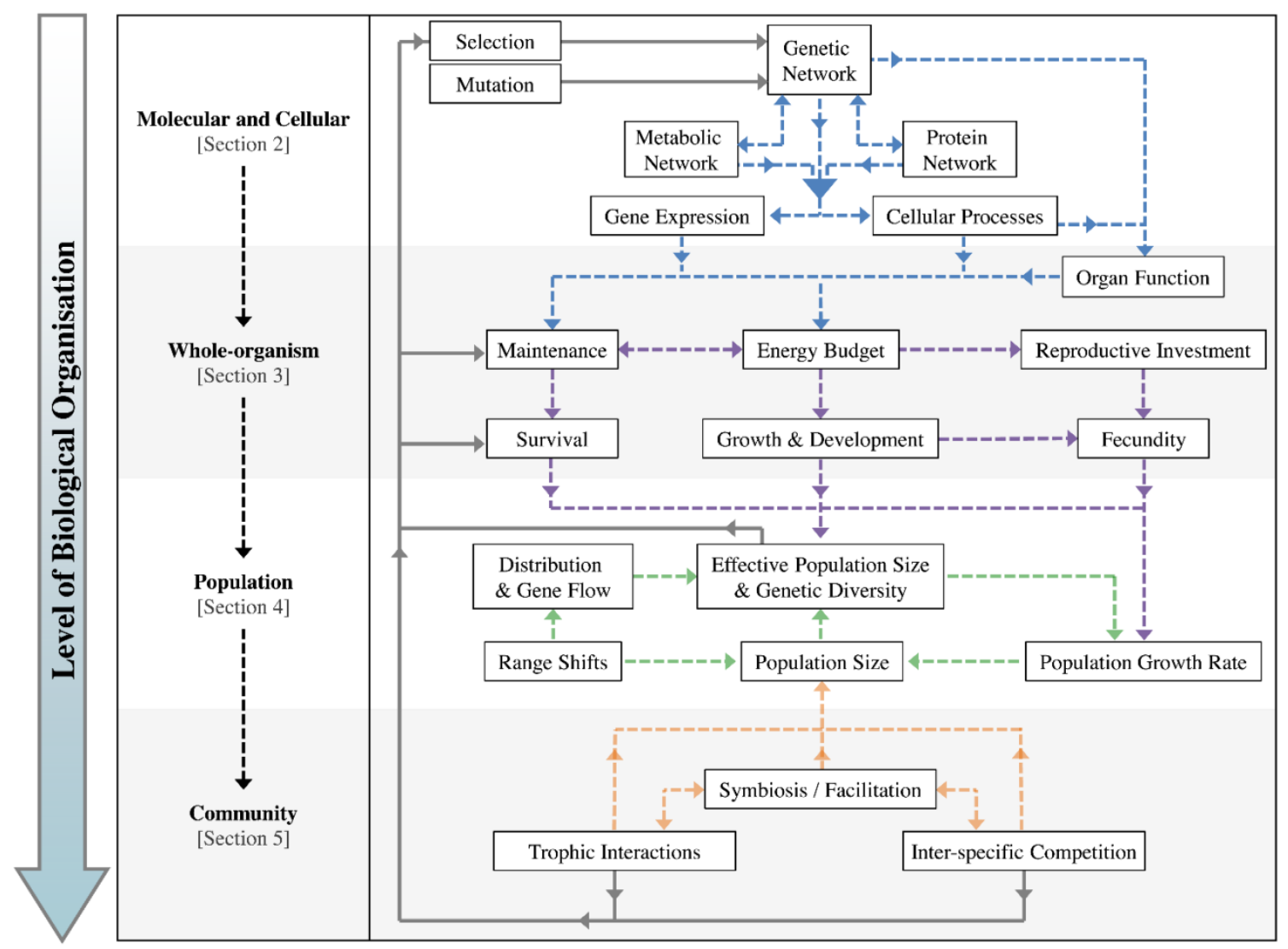

\subsection{Biochemical Reactions and Gene Expression}

Within the organism, protein activity is often thought to underlie variations in fitness (for discussion, see [30]). Fitness at the biochemical level could be simply considered as the ability of proteins to function (within their respective intra- and extra-cellular setting) in order to integrate the diverse functions of cells and organelles [31]. Proteins are responsible for crucial functions in all biological processes [31], and evolutionary changes can occur through changes in the proteins themselves (e.g., post-translational modifications), the encoding gene(s) of those proteins, or the transcription of those encoding genes [31].

Fitness-related traits can be influenced through genetic variation in these proteins, such as the collinearity of gene mutations, whereby the point mutations in the DNA sequence will correspondingly change the sequence of amino acids in a protein [32]. These biochemical consequences can influence 
protein function and in turn, tolerances to environmental conditions [33]. For example, a minor mutation (only two amino-acids out of 334) in a dehydrogenase enzyme in the temperate mussel Mytilus galloprovincialis (Lamarck, 1819) resulted in higher thermal tolerance towards warm conditions [34]. Alternatively, enzymes possessing alternative alleles, such as for lactate dehydrogenase-B in cold- and warm-adapted populations of the killifish (Fundulus heteroclitus L., 1776) [35], may be able to confer adaptation potential for thermal tolerance through variable allele frequencies.

In order to produce adaptive phenotypes, changes may be required in multiple combinations of alleles [36]. Allelic changes are embedded within genetic networks and hence, will not occur independently to other changes, since any allelic changes at a particular locus will influence only one aspect of a genetic network [37]. These genetic networks essentially consist of the genes which encode the transcription factors as the input for each coding gene, and the cis-regulatory modules that control the appropriate phases of expression of these genes [38]. Gene regulatory networks control the expression of genes in any given developmental process [39], including fitness-related traits, and therefore, any changes in the networks could play an important role in adaptive evolution and climate change responses [37].

Environmental effects may cause changes either in specific genes within the network, influencing their gene expression, or affect the gene regulatory network as a whole [40]. Genetic networks will primarily be influenced by current environmental conditions and maternal effects (the latter described in Section 2.3), and these changes will, in turn, alter the protein and metabolic networks that influence gene regulation (via a feedback loop reaction) [37]. Changes in genetic networks may influence plastic responses and facilitate adaptive evolution by providing a rapid response to the changing environmental conditions. However, if the genetic regulatory network is influenced by other factors that do not follow the changing environmental conditions, such as photoperiod [41] or even biotic interactions [42] (discussed further in Section 5), then adaptive evolution might require a restructuring of the genetic network in order to conform to the novel environmental conditions [37].

Currently it remains unclear whether the few examples that demonstrate observable adaptive evolution of traits in response to climate change (e.g., body size [43], migration timing [44], thermal responses [45]) are dictated by various independent genes (within their respective genetic networks), or by fewer key regulatory genes within their genetic or metabolic networks. This is important to consider since any changes in the 'upstream' network genes could have extensive and numerous effects on traits [37], and yet the network itself may also provide some redundancy and buffering against perturbations, whereby changes to regulatory genes do not influence the genes they regulate [46]. Eventually, it may be possible to identify common genetic (e.g., collinearity in the gene order between genomes [47]) and physiological mechanisms underlying species responses [17]. However, studies demonstrating a clear link between the genetic variation and phenotypic variation for the majority of traits are scarce (but for example, see [48]). Therefore, any studies of genetic variation should focus on traits with more straightforward or measurable relationships to fitness [17,21].

Establishing the evolutionary significance of cellular-level plasticity (i.e., the changes in the expression levels of stress-related genes, e.g., [49]) requires demonstration of a heritable component of expression variation, or allelic variation in the coding genes themselves [17,50]. Accurately estimating selection responses requires the genetic component of this variation (in regulatory responses) to be related to the fitness of the organism $[51,52]$ in order to ascertain the fitness-related consequences for 
the individual and the population. This highlights the need to investigate transcriptome profile responses in terms of survival, fecundity, or other ecologically important traits that determine lifetime reproductive success (but see [30] for a discussion on the limitations in the link between the transcriptome and the phenotype), and importantly, ascertain whether sufficient genetic variation exists in that trait [53].

\subsection{Cellular Processes and Organ Function}

Cellular and organ functioning during stressful conditions will primarily be dictated by changes at the genomic and biochemical level (Section 2.1). The principal factor determining the underlying cellular stress response (a universally conserved mechanism to protect macromolecules within cells from damage [54]) depends on the extent of stress-induced disturbances (reviewed by [55]). During moderate stress, resources may be shifted from anabolic (e.g., protein biosynthesis) towards vital processes for cellular homeostasis (e.g., ion regulation; [55]) to maintain cellular integrity and ensure short-term survival. However, on longer time scales such shifts may not be feasible and might lead to a reduction in organism performance (e.g., reduced growth rates or fecundity) since the organismal energy budget can be considered as the sum of all cellular energy budgets [55].

Such trade-offs in physiological functions could have important fitness consequences, but may not be apparent when only observing the whole organism level. For instance, a study on the effects of ocean acidification on the reef-building coral, Acropora millepora (Ehrenberg, 1834), reported major changes in gene expression and cell physiology long before phenotypic effects were observed, in this case, a decrease in calcification rates [54]. Thus, cellular functioning might play a central role in linking environmental conditions to an organism's fitness [56], and the plasticity and adaptive evolution of cellular processes may be an important influence on species resilience towards changing environmental conditions.

Adaptive evolution in cellular function may be possible through gene duplication [57-59], whereby paralogous genes (i.e., gene copies) that perform a particular function either increase their expression (increased gene dosage) or diverge their functions through mutation [60]. This divergence can be achieved by one of the copies acquiring a new function, or through a partial loss-of-function mutation of both copies that complement each other [61], while retaining the full set of functions (termed sub-functionalisation [60]). This sub-functionalisation is a relatively common mechanism for functionally related proteins [61], such as components of cell signalling pathways, and may facilitate evolution of advantageous traits: e.g., a changed $\mathrm{pH}$ optima of proteins [62], a beneficial trait for maintaining acid-base homeostasis in response to ocean acidification.

\subsection{Epigenetics and Trans-Generational Plasticity}

The environment experienced by an organism can shape the phenotype of their offspring, and is termed trans-generational plasticity (e.g., [63]). Trans-generational plasticity can be due to maternal or paternal effects, genomic imprinting, gene expression or other epigenetic processes. These epigenetic effects (whether a gene is being expressed or not) can be transmitted through the germ line [64], which can allow for transmission through meiosis to the succeeding generation, constituting a heritable, epigenetic change [65]. For example, five weeks exposure to elevated $p \mathrm{CO}_{2}$ during the reproductive 
conditioning of Sydney rock oysters (Saccostrea glomerata, Gould 1850) reduced the development time and increased the body size of their larvae through trans-generational plasticity [66].

Mechanisms exist that should allow these epigenetic changes to result in localised changes in the DNA sequence, such as changes in the activity of chromatin-modifying enzymes [65]. Providing they exert the same functional effect, any epigenetic effects can potentially become a genetic change, and exert a selectable phenotypic response [65]. During climate change, the environmental conditions that induce these epigenetic effects (like temperature) will persist (albeit progressively increasing) and therefore with each successive generation, the epigenetic response could actually result in continued DNA change in selected regions of the genome [65].

The gene regulatory network, responsible for many fitness-related traits (Section 2.1), is initiated by maternal transcripts and proteins, which cascade into subsequent gene regulatory interactions [67]. Early genes that function during development (such as for larval morphology) can be influenced by the fitness traits of the maternal parent (e.g., by changes in egg size or provisioning [67]), and therefore it may be possible that parental exposure to climate change can cause DNA (or heritable, epigenetic) changes that promote adaptive evolution in key regulatory genes, or the genetic network as a whole.

\section{Role of Whole-Organism Physiological and Behavioural Responses}

Marine organisms possess a range of reproductive and developmental strategies that have important implications for their fitness [68]. Different reproductive modes, life histories, and demographic processes can influence these strategies [69-71]. In this section we focus on how climate change, specifically ocean acidification and warming, can influence the physiology and behaviour of the individuals, affecting their survival and fitness. It is important to consider the factors that influence selection at this level of biological organisation in order to link individual phenotypes, which are in turn driven by transcriptional and cellular processes, to population-level effects.

\subsection{Maintenance and Energetic Trade-Offs}

The capacity to maintain metabolic processes under environmental stress may support (or promote) the retention of particular life history traits (such as reproductive output) that may ultimately determine a species' biogeography [72,73]. A recent study using an in situ transplant experiment with polychaetes, found that species capable of maintaining their metabolic rates (under stress) were able to migrate into or even colonise areas characterised by chronically elevated levels of $p \mathrm{CO}_{2}$ [26]. This high- $\mathrm{CO}_{2}$ tolerance was achieved in the polychaetes via acclimatisation for Amphiglena mediterranea (Leydig, 1851) and by adaptation for Platynereis dumerilii (Audouin \& Milne-Edwards, 1834) [26]. However, such resilience often comes at a cost [74]. The individuals of $P$. dumerilii were smaller in body size compared to nearby populations in lower $\mathrm{pCO}_{2}$ conditions, attributed to increases in maintenance costs due to a higher mean metabolic rate under chronic exposure to elevated $p \mathrm{CO}_{2}$. Since the size (in several polychaete species) can determine the maximum numbers of eggs that a female produces, this resilience could result in reduced reproductive output [26]. Although the study did not empirically test this, any reallocation of energy away from reproduction would clearly have important implications for lifetime reproductive success. 
Fitness-related traits can be genetically correlated to each other and, depending on strength and direction of selection, influence the potential for adaptive evolution (for more detail, see [17]). Briefly, a positive correlation could include a co-tolerance to multiple stressors (e.g., developing sea urchin larvae obtaining tolerance to low $\mathrm{pH}$ and therefore also temperature [75]), or a selection for a particular trait providing tolerance for another trait (e.g., growth and disease resilience in Sydney rock oyster (S. glomerata) providing tolerance to high $p \mathrm{CO}_{2}$, [66]). If the intra-individual physiological mechanisms (Section 2) and an organism's response during climate change are nonlinearly related, then there is a need to understand what physiological trade-offs are occurring that are influencing their fitness related traits. Fitness trade-offs will certainly influence potentially selected traits, if other energetically maintained traits are selected over survival or reproductive output.

\subsection{Life-History Stages}

Research into physiological responses to climate change has demonstrated that fitness traits, such as reproduction and development, are likely to be disproportionally affected [76-78]. Since natural selection acts upon lifetime reproductive success, climate change can reduce fitness through impacts on early life-history stages, such as an increase in developmental duration or number of defects [79-81]. However, many marine species have complex life histories, and despite early life history stages being considered to be particularly vulnerable to climate change [82], there is increasing evidence that selection pressures act on each life stage differently (e.g., [83]). Phenotypic carry-over effects can also occur between life history stages (as well as trans-generationally, Section 2.3) that could exacerbate or alleviate the impacts on fitness-related traits. For example, exposure to stressful conditions during the larval stage can reduce the juvenile fitness if those conditions continue (e.g., [84]). This may be particularly important given that different stages of ontogeny may utilise different habitats (e.g., [85]) or exhibit different behaviour. Hence, impacts considered on individual life-stages may not accurately estimate the fitness response of a given species [86].

\subsection{Behavioural Responses}

Organismal behaviour is mediated by multiple external and internal sensory inputs that may be changed directly and indirectly by climate change [87]. The plastic behavioural responses observed in organisms are largely a direct physiological response to a changing environment, since the nervous system is under biochemical and physiological control [88]. Hence, changes in the underlying physiological condition (see Section 2) could influence behavioural performance by constraining an ecologically-relevant behaviour, such as swimming activity [89]. A study in coral reef fish found that small temperature increases $\left(<3{ }^{\circ} \mathrm{C}\right)$ contributed to changes in animal personality (activity, boldness, aggression), thought to be linked to individual responses in energy metabolism [90].

Changing environments can also modulate behaviour by interfering with sensory inputs and neural functioning. For example, elevated levels of $p \mathrm{CO}_{2}$ are hypothesised to remodel the sensory pathway of the GABA-A system of marine organisms, including the larval clownfish (Amphiprion percula Lacepède, 1802), damselfish (Neopomacentrus azysron Bleeker, 1877), and gastropod Gibberulus gibbosus (Röding, 1798) [91,92], causing sensory and behavioural impairment, including learning ability [93]. This phenomenon is thought to be associated with ion regulatory mechanisms during high 
$\mathrm{CO}_{2}$ exposure (accumulation of intracellular $\mathrm{HCO}_{3}{ }^{-}$and $\mathrm{Cl}^{-}$), which interfere with neurotransmitter functions (for more details, see [92]). Impaired learning regarding the identity of predators during high $p \mathrm{CO}_{2}$, or diminished detection of the olfactory cues for settlement (for instance) influence fitness by negatively affecting the survivorship of the individual $[93,94]$. Sensory pathways occur in differing complexities with receptors and messenger systems of different adaptive potential [95]. Hence, knowing the mechanistic pathway of a behavioural response is important for determining the evolutionary potential of an organism or indeed a trait. Linking these pathways with their genes is important for finding out if organisms can adapt, in order to cope behaviourally with environmental stressors [96]. Behavioural traits may be more evolutionary labile than other traits [97], and may contribute to or hinder adaptation $[19,98]$.

\section{Role of Population-Level Responses}

Focusing on population-level organisation is crucial for connecting the fitness responses of lower levels (individual/population) to changes in higher levels (species/community). The analysis of microevolution in populations requires an understanding of how environmental changes influence evolutionary processes such as gene flow, mutation, genetic drift and natural selection [99]. Historically, the concept and investigation of population level adaptation in the marine environment was largely dismissed; it was assumed that marine connectivity would maintain high levels of gene flow between populations via adult and larval dispersal [100], and so impede local adaptation. However, new evidence compiled by Sanford and Kelly [101] shows that microevolution is not restricted to organisms with low dispersal abilities. Through a literature survey Sanford and Kelly [101] found that $66 \%$ of marine invertebrates with planktonic life stages for dispersal, i.e., meroplankton, present highly adaptive differentiation at the population level (e.g. Haliotis rufescens, Table 1). Depending on the taxa investigated, the planktonic dispersal stages of the identified (66\%) invertebrates experienced brief (up to a few days as with some corals, sea anemones or ascidians) to prolonged (several weeks to longer, some crustaceans and gastropods [100]) planktonic larval durations.

\subsection{Demographic Processes}

Populations can respond to environmental pressures more rapidly through range shifts and phenotypic plasticity rather than through evolutionary adaptation [102]. Evolutionary responses are likely to vary depending on the cost of adaptation, timescale, life-history and dispersal ability in addition to other factors [19]. Different evolutionary responses have been previously investigated and require a variety of techniques (for a survey of selected reference studies see Table 1). Understanding genetic variation, as well as specific population dynamics, is crucial to explore the potential for evolutionary rescue [103]. For example, populations in isolated environments, such as the Baltic Sea, may also undergo isolation and develop genetic endemism as a result of local extinctions or adaptation by evolutionary rescue [104]. Therefore, population size and genetic variation in the context of the intensity and duration of environmental selection pressures must be considered [105] to identify what part of the population (i.e., the effective population size [106]) contributes to the next generation. 
Table 1. Published studies investigating population level evolutionary responses to climate change (including ocean acidification) in marine species.

\begin{tabular}{|c|c|c|c|c|c|}
\hline Taxonomic Affiliation & $\begin{array}{c}\text { Response } \\
\text { Variable(s) } \\
\end{array}$ & Driver & Method(s) & Evolutionary Response & Ref. \\
\hline $\begin{array}{l}\text { Spermatophyta: } \\
\text { Zostera marina }\end{array}$ & $\begin{array}{c}\text { Growth rate } \\
\text { Survival } \\
\end{array}$ & $\mathrm{T}$ & $\mathrm{F}$ & Genotypic complementarity & [107] \\
\hline $\begin{array}{c}\text { Coccolithophyceae: } \\
\text { Emiliania huxleyi }\end{array}$ & $\begin{array}{c}\text { Growth rate } \\
\text { Production rate: (PIC) }\end{array}$ & OA & LS & $\begin{array}{c}\text { Selection of genotypes } \\
\text { Direct positive adaptation }\end{array}$ & [108] \\
\hline Gephyrocapsa oceanica & $\begin{array}{c}\text { Growth rate } \\
\text { Carbon fixation }\end{array}$ & $\mathrm{OA}$ & LS & Selection of genotypes (Adaptation) & [109] \\
\hline $\begin{array}{c}\text { Diatomophyceae: } \\
\text { Thalassiosira pseudonana }\end{array}$ & $\begin{array}{c}\text { Phytosynthetic } \\
\text { efficiency }\end{array}$ & $\mathrm{OA}$ & LS & No adaptation & [110] \\
\hline $\begin{array}{c}\text { Anthozoa: } \\
\text { Acropora millepora }\end{array}$ & $\begin{array}{c}\text { Thermal and } \\
\text { physiological } \\
\text { tolerance }\end{array}$ & $\mathrm{T}$ & $\mathrm{F}$ & Natural selection & [111] \\
\hline Pocillopora damicornis & $\begin{array}{c}\text { Coral bleaching } \\
\text { (thermal tolerance) }\end{array}$ & $\begin{array}{c}\mathrm{T} \\
\mathrm{ES}\end{array}$ & CG & Local adaptation or acclimation & [112] \\
\hline $\begin{array}{c}\text { Bivalvia: } \\
\text { Mytilus trossulus }\end{array}$ & $\begin{array}{c}\text { Growth rate } \\
\text { Survival }\end{array}$ & $\mathrm{T}$ & $\mathrm{TE}$ & Possible thermal adaptation & [113] \\
\hline $\begin{array}{c}\text { Gastropoda: } \\
\text { Haliotis rufescens }\end{array}$ & $\begin{array}{c}\text { Genetic } \\
\text { polymorphism }\end{array}$ & $\mathrm{T}$ & SNP & $\begin{array}{c}\text { Local adaptation } \\
\text { Genetic differentiation }\end{array}$ & [114] \\
\hline $\begin{array}{c}\text { Polychaeta: } \\
\text { Platynereis dumerilii }\end{array}$ & Body size & $\mathrm{OA}$ & $\mathrm{TE}$ & Genetic adaptation & [26] \\
\hline Amphiglena mediterranea & Body size & $\mathrm{OA}$ & $\mathrm{TE}$ & Physiological plasticity & [26] \\
\hline $\begin{array}{c}\text { Amphipoda: } \\
\text { Orchestia gammarellus }\end{array}$ & $\begin{array}{c}\text { Growth } \\
\text { Thermal tolerance }\end{array}$ & $\mathrm{T}$ & LS & Selection & [115] \\
\hline $\begin{array}{c}\text { Cirripedia: } \\
\text { Semibalanus balanoides }\end{array}$ & $\begin{array}{c}\text { Genetic } \\
\text { polymorphism }\end{array}$ & $\begin{array}{l}\mathrm{T} \\
\mathrm{D}\end{array}$ & $\mathrm{TE}$ & $\begin{array}{c}\text { Balancing selection } \\
\text { Local adaptation }\end{array}$ & [116] \\
\hline $\begin{array}{c}\text { Copepoda: } \\
\text { Tigriopus californicus }\end{array}$ & $\begin{array}{c}\text { Survival }\left(\mathrm{LT}_{50}\right) \\
\text { Thermal plasticity }\end{array}$ & $\mathrm{T}$ & LS & Low adaptation potential & [117] \\
\hline $\begin{array}{l}\text { Decapoda: } \\
\text { Uca pugnax }\end{array}$ & Developmental rate & $\mathrm{T}$ & CG & $\begin{array}{c}\text { Selection on variation } \\
\text { Local adaptation }\end{array}$ & [118] \\
\hline $\begin{array}{l}\text { Echinoidea: Heliocidaris } \\
\text { erythrogramma armigera }\end{array}$ & Hatching success & $\mathrm{T}$ & QG & Genotype-by- environment interaction & [119] \\
\hline $\begin{array}{c}\text { Strongylocentrotus } \\
\text { purpuratus }\end{array}$ & $\begin{array}{l}\text { Gene expression: } \\
\text { thermal resistance }\end{array}$ & $\mathrm{T}$ & $\mathrm{CG}$ & Selection of thermally sensitive genes & [120] \\
\hline $\begin{array}{c}\text { Strongylocentrotus } \\
\text { purpuratus }\end{array}$ & Larval body size & $\mathrm{OA}$ & CG & Heritability correlates with high- $p \mathrm{CO}_{2}$ & [121] \\
\hline Centrostephanus rodgersii & $\begin{array}{c}\text { Cleavage and } \\
\text { gastrulation stage }\end{array}$ & $\begin{array}{c}\mathrm{T} \\
\mathrm{OA}\end{array}$ & QG & Heritable genetic variation for sires & [75] \\
\hline Centrostephanus rodgersii & $\begin{array}{c}\text { Embryonic } \\
\text { development }\end{array}$ & $\begin{array}{c}\mathrm{T} \\
\mathrm{OA}\end{array}$ & $\mathrm{CG}$ & Varying expansion of population & [122] \\
\hline $\begin{array}{c}\text { Teleostei: } \\
\text { Gadus morhua }\end{array}$ & Body shape & $\mathrm{T}$ & $\mathrm{CG}$ & Counter-gradient variation & [123] \\
\hline Fundulus heteroclitus & Thermal tolerance & $\mathrm{T}$ & LS & $\begin{array}{c}\text { Selection } \\
\text { Regulation of heat shock proteins }\end{array}$ & [124] \\
\hline
\end{tabular}

Notes: Selective driver: abbreviated as T - temperature; OA - ocean acidification; ES - environmental stability; D - desiccation. Method: F - field experiment; LS - laboratory selection experiment; CG - common garden experiment; TE - transplant experiment; SNP - outlier SNP analysis; QG - quantitative genetics. 
Populations may have an increased chance of persistence if they react to changing climatic conditions with higher phenotypic plasticity. Should this plasticity occur in a fitness-related trait, then this may present a heritable variation for selection to act upon (e.g., [23,125]). This mechanism would thereby allow for a faster non-mutational selection [126]. Populations that are maladapted to climate change will likely experience an initial decline and thus, a reduced effective population size [127]. Phenotypic buffering, a type of phenotypic plasticity, represents an important mechanism for maintaining population performance under stressful conditions until adaptive evolution can "catch up" and sufficiently improve population fitness $[23,128]$. For example, genetically diverse populations of the seagrass Zostera marina (L., 1758) showed quicker recovery following sub-lethal temperature stress when compared to less diverse populations [107]. This buffering effect was expressed due to the complementarity of different genotypes (e.g., facilitation) that maintained ecosystem functioning, and may promote adaptive evolution [107].

\subsection{Environmental Variability}

The potential for adaptation under naturally low or fluctuating $\mathrm{pH}$ can be studied in regions of upwelling along the continental coast of (Western) North America [129]. A transcriptomic analysis of sea urchin larvae (Strongylocentrotus purpuratus Stimpson, 1857) collected from a naturally variable low $\mathrm{pH}$ upwelling site revealed that larvae under present day conditions initiated a robust transcriptional response, but only a muted response to near future conditions [130]. These exposures to transient extreme conditions may be sufficient to provide populations with a selection for tolerance (e.g., [131]). However, the question then becomes whether selection for one stressor will provide increased tolerance to another. Quantitative genetics is a technique that may help answer this type of question because it allows partitioning of the observed phenotypic variance of a population among relatives (with known genetic relatedness) into their environmental and genetic components [132], in a synchronic approach (sensu [23]). Numerous studies have demonstrated evolutionary adaptive capacity using quantitative genetics (as reviewed in [71]).

In the absence of mutations, adaptive evolution relies on the genetic variation in physiological tolerances [133], this is because in turn, the variation of physiological tolerances influences the likelihood of extinction [121,134]. These tolerance traits in natural populations are termed standing genetic variation, and arguably the most important influence maintaining this adaptive variation is spatially varying selection [135]. For most species, the temperature gradient across their distribution (e.g., $30{ }^{\circ} \mathrm{C}$ difference between the pole and equator [121]) will greatly exceed the expected future temperature change $\left(3.7-4.8^{\circ} \mathrm{C},[136]\right)$. In contrast, $\mathrm{pH}$ gradients are often relatively homogenous when compared to predicted change $(0.3-0.5 \mathrm{pH}$ units by 2100 [136]; but see $[129,137,138])$. Therefore, populations may possess greater adaptive variation for temperature tolerance, but have less adaptive variation for $\mathrm{pH}$ tolerance [117].

It is crucial to distinguish between microevolutionary (genetic) and phenotypic (plastic) responses at the population level. Many past studies have lacked this focus, but identifying the drivers responsible for changes in fitness traits should be given more attention in future studies (e.g. $[19,139])$. Non-genetic evidence can also be lacking, missing potential patterns, such as in situations of counter gradient variation whereby genetic and environmental influence can oppose each other [140]. This was the case 
for the genetic divergence of body shape between two populations of juvenile Atlantic cod (Gadus morhua L., 1758), in which phenotypic differences were mitigated by environmental influences [123]. Even the positive, negative or neutral correlation between two fitness traits may accelerate, slow down, or not impact adaptive evolution [17]. As such, local environmental variability must be considered when determining population responses.

\subsection{Modes of Population-Level Response}

Examination of time series data reveals evolutionary responses to climate change, such as direct allochronic studies which include a mixture of populations that are on their way to adaptation or extinction (reviewed in depth by [102]). These studies can show that the selection of genotypes is an immediate mechanism of population-level adaptation. Multi-generational analysis of selection of the coccolithophore (Emiliania huxleyi (Lohmann) Hay \& Mohler, 1967) has provided evidence for evolutionary adaptation responses detected by selection of genotypes and direct positive adaptation to increased $p \mathrm{CO}_{2}$ by mutation [108]. However, it is important to emphasise that the rate of adaptation for single-celled organisms, due to their fast generation times, will likely differ along with the mechanisms utilised when compared to multi-cellular organisms. Future studies should be optimised by an interdisciplinary approach, including abiotic changes driven by climate change, biological networks, and the relationship between the phenotypic and genetic analysis, for a better understanding of future climate change impacts on the evolution of populations.

\section{Community Composition and Interactions}

While studies of evolution on single species and populations are already underway (either in situ or in the laboratory), the potential of communities and ecosystems to evolve as a unit in response to changing environments has not yet received as much attention. This is partially due to the complex nature of communities. Another important reason is that for several decades, ecological and evolutionary time scales were thought to diverge widely and this has led to very different thought models of evolution and ecology [141]. In particular, it was thought that evolution takes place in time frames that cannot influence ecology, while the effect of ecology on evolution has been studied in some prominent examples. For instance, in the Atlantic cod (Gadus morhua L., 1758) fishing pressure led to earlier age at maturation [142]. However, the dynamic effect of evolution on ecology is an emerging field of study since it was recognised that evolution of ecologically relevant traits can influence contemporary communities [143,144].

If community composition is altered, the coevolution between interacting species will be driven and/or modified by their interactions within the community [145,146]. This diffuse coevolution means that the selection of a specific trait in one species may depend on the presence of another species [147], making species identity and uniqueness a plastic response in community-level responses [148]. Therefore, the effects of future climate change on communities will likely be complex [149], and influence the outcomes of competition, facilitation (e.g. [150]) and trophic interactions (e.g., predatorprey [151,152], and plant-herbivore [153,154]). 


\subsection{Changes to Community Dynamics}

The fast population turnover of single-celled phytoplankton represents a great opportunity to study experimental evolution and to quantify evolutionary and plastic responses of populations to future climate change [155]. Phytoplankton communities represent a pivotal role in marine ecosystem functioning [155], forming the base of the marine food web and crucial for global biogeochemical cycles [156]. Under current conditions of dissolved inorganic carbon, many phytoplankton species are not fully saturated for growth and photosynthesis, and therefore, will benefit from the addition of $\mathrm{CO}_{2}$ (e.g., [157-159]). However, any selection for fast growth, despite providing competitive ability through size (but see [160]), may come at the cost of reduced resilience to $p \mathrm{CO}_{2}$ [161]. This was shown by a study ([161]) that used genetically distinct isolates of phytoplankton species (sixteen strains of the diatom Skeletonema marinoi, Sarno \& Zingone 2005 and eight strains of dinoflagellate Alexandrium ostenfeldii (Paulsen) Balech \& Tangen, 1985) and found that slow-growing cultures generally responded positively to elevated $\mathrm{pCO}_{2}$, while fast-growing cultures either showed neutral or negative responses. Hence, the effects of climate change need to be considered holistically in terms of both ecological performance as well as physiological tolerance.

The enormous diversity of phytoplankton and the variety of environmental stressors makes it unthinkable to experimentally test all the possible trait responses in every phytoplankton group. The difficulty lies in establishing whether this evolutionary potential can be realised, and whether results from laboratory experiments can be related to natural populations (see [155]). Therefore, understanding the mechanistic effects of future climate change on key functional groups (e.g., [162]) will require a deeper understanding, across biological hierarchies, of the direct effects on their physiology (molecular and cellular), basic biology (whole-organism), as well as estimates of gene flow, population size, and recombination rates (population) [155].

In order to extrapolate from the organism and individual species' responses to the community level, we also need to understand the response of the ecological interactions within the community. For example, any increased biomass associated with higher atmospheric $\mathrm{CO}_{2}$ may be indirectly mediated by the presence of grazers (indirect trophic interactions, e.g., [163]), or regulated by heterotrophs of the same community (e.g., [164]). Similarly, phytoplankton responses associated with climate change can lead to bottom-up control (e.g., [165]), or, due to sufficient food availability to marine organisms may provide physiological homeostasis (e.g., Mytilus edulis L.; 1758 [166]). As such, if the effects of climate change differ between similar co-existing species (e.g., [167]), it may indirectly influence selection by causing ecological release; reducing the need for competitive traits.

In addition to the direct effects, future climate change may have indirect effects on other communities. Where $\mathrm{CO}_{2}$ is a resource for organisms, it can play an important role leading to changes in community competition (e.g., [168]). For example, opportunistic turf- and mat-forming algae have been demonstrated to inhibit other taxa (e.g., [169]) and outcompete kelp recruitment (e.g., [170]), inducing phase shifts. Species in diverse communities tend to have lower effective population sizes compared to when they are in isolation due to the competitive interactions [171]. This typically increases the role of genetic drift compared to selection, and might reduce the rates of adaptive evolution [172]. Climate change might reduce those inter-specific interactions (e.g., bottom-up control releasing resource limitation [165]) and thereby enhance the potential for adaptation, through reductions in genetic drift. 
Alternatively, climate change may increase competition (e.g., [173]) and amplify changes in mean population size, increasing extinction risks, as well as decreasing adaptation rates (Figure 1). This may be further exacerbated through co-extinctions, due to increased habitat and biodiversity loss, whereupon one species is dependent on another that is already extinct [174].

The presence of co-occurring species might enable adaptation by initiating coevolutionary interactions (e.g., [175]), however, it has also been suggested that increasing biodiversity may begin to inhibit that subsequent adaptation (e.g. [171]). This is due to an increased number of species in an assemblage, increasing the chance that a current species will possess traits that would predispose the species towards favourable selection under future environmental conditions, and could restrict the opportunity of other co-occurring species to adapt. Species-specific adaptation mechanisms could ultimately feedback to influence ecosystem functioning [143]. For example, three bacterial species that were raised together had higher productivity compared to the same species that adapted isolation [176]. This was due to the inter-specific competition that caused them to select for specialisations in their resource use (niche partitioning [177]), leading to a complementary adaptation [176]. Hence understanding whether the evolutionary potential can be realised will require investigations that utilise realistically diverse assemblages (e.g., [169,173]). It does however, also raise the challenge of understanding whether future ecosystems will become sustained ecosystems (with fewer species that are selected for their favourable traits), or more evolved ecosystems as a whole. This is crucial given the extensive research regarding biodiversity and ecosystem multi-functionality in present day communities (for more details, see [178]).

\subsection{Habitat Fragmentation and Biological Invasions}

Anthropogenic climate change is expected to reorganise patterns of species diversity $[179,180]$. One possible approach for investigating the selection response using naturally assembled communities is through the use of natural analogues for future climate change, such as $\mathrm{CO}_{2}$ vents [26], or coastal upwelling sites [114,181]. These areas provide long-term chronic exposure to novel environmental conditions, and allow experimental work to capture an organism's response in fitness-related traits [26,182], such as reproductive success. Moreover, organism responses will include carry-over effects (between life-history stages and trans-generationally), as well as being influenced by other ecological interactions, such as competition and trophic interactions. Yet, (a caveat) for those species that are not direct-developing, these sites may be confounded by larvae received from outside of the site, with different environmental conditions, likely reducing selection pressure.

For long-lived sessile foundation species, such as reef-building corals, evidence suggests that acclimatisation and adaptation will be essential for population persistence in the face of climate change [25], given that any range shifts are likely to be slow [183]. A recent transplant experiment utilising the table top coral (Acropora hyacinthus Dana, 1846) found that acclimatisation and adaptive responses (mirrored in the patterns of gene expression) allowed this faster-growing coral to inhabit areas of the reef that far exceeded their expected temperature tolerances [25]. This tolerance to elevated temperature might be associated with either the coral host (e.g., [48,184]), or their associated Symbiodinium (e.g., [185]). In contrast, experimental work investigating the coral reefs at the shallow volcanic $\mathrm{CO}_{2}$ seeps (in Papua New Guinea) found an overall reduction in diversity and recruitment in 
the coral communities pre-acclimated to high $\mathrm{pCO}_{2}$, thought to be associated with shifts in competitive interactions [173]. This highlights that the adaptive evolution of coral reef communities is possible and driven by abiotic factors (Court Jester hypothesis, [186]), however, community-level interactions (such as the increased competition in high $p \mathrm{CO}_{2}$ ) may equal or exceed these fitness-related responses (i.e., survival), and lead to adaptive evolution being driven by biotic factors (Red Queen hypothesis, [186]) Clearly, the relative roles of biotic and abiotic factors will be stressor-specific reaffirming the need to investigate the adaptive evolution responses with multiple stressors in realistic communities.

Biological invasions are important drivers of change in marine communities, particularly coastal communities (e.g., [187,188]). Increases in temperature may facilitate species' range shifts, thereby aiding invasion [188]. One particular example of this is the 'tropicalisation' of the Mediterranean Sea, where, invasions and establishments have been made possible due to increasing annual mean temperatures all year around [189]. The integration of novel species may influence evolutionary processes by altering existing interactions (e.g., [190]) or population growth rates (see [191]). Alternatively, both the native and non-native species may be able to achieve coevolution if their co-existence can maximise their habitat use [192]. Although native species might be able to overcome the invasion of some non-natives, some may become less adapted to the new conditions and be out competed by invasive organisms, which exhibit greater adaptability or the ability to demonstrate strong fitness effects [188].

\section{Future Directions}

It is inevitable that increasing ocean acidification will be accompanied by changes in other abiotic factors, and therefore interactions with other stressors (i.e., temperature, nutrients, hypoxia or salinity) are extremely likely [193]. For both single and multiple stressors, there is a crucial need to incorporate the potential for adaptation to future climate change, to reliably determine the sensitivity and mechanisms for adaptation of marine organisms.

Adaptation capacity will be driven through a number of mechanisms with different taxonomic and functional groups utilising a variety of processes. Species with large population sizes and fast population turnover rates, such as phytoplankton, are likely to demonstrate the potential to achieve the adaptation rates required for future climate change (e.g., [108]), making them a model species for laboratory experimental evolution. However, these experiments will likely be carried out in the absence of more complex trophic and ecological interactions. In order to clarify the effects of anthropogenic climate change on community- and ecosystem-levels, future research should be directed towards identifying key species, and establishing their interactions with coexisting species, particularly if those ecological interactions vary with season or ontogeny $[194,195]$. The choice of species could be associated with the needs for either ecosystem's services or functioning, such as the disproportionate role that coccolithophores play in the carbon-cycle, or societal needs, such as for food security, or possibly in an ecological context, being habitat forming or a keystone species.

Given the differential sensitivities and responses of different life-stages, future research needs to identify which life-stages are most affected by climate change and the key interactions (among species and to different climatic scenarios) within ecosystems [196]. The negative results from short-term studies on early life-stages often make it difficult to extrapolate to longer-term impacts [197-199], especially 
when multiple stressors interact, since the sensitivity of early life-stages may not be representative when responses are considered across all ontogeny and life-stages. The exposure of previous generations to environmental conditions will influence the response of subsequent generations (i.e., carry-over effects). As such, the use of chronic long term multigenerational experiments should contribute to our understanding of both developmental and trans-generational plasticity [108,155,198]. An additional important consideration is the current local-scale variability of environmental conditions. If the adverse conditions that we expect by the end of the century are already being experienced by marine organisms, and are within the range of the current environmental variability (e.g., $\mathrm{CO}_{2}$-enriched upwelling, Kiel Fjord, western Baltic Sea [138]), then these transient extreme conditions may result in a pre-selection for tolerance (e.g., [131]). This pre-selection might be achieved through the divergent selection of specific genes in candidate loci (e.g., [114]), and contribute to the maintenance of positive life-history traits.

Phenotypic plasticity may provide the potential for species to achieve sufficient tolerance in the short-term, such that they may actually be able to achieve adaptation to environmental change. To attain a mechanistic understanding of this process will require an interdisciplinary approach, including investigations at different levels of biological hierarchy. This is because the capacity of a species' phenotypic plasticity might be set at the cellular level, for example through changes in oxygen demand via mitochondrial activity. However, it is important to consider that these responses might be first observed through changes in abundance (or distribution), using more phenomenological approaches at the population level. Alternatively, the persistence of a species could be attributed to its dispersal ability and the availability of suitable habitat and hence potential spatial scale of gene flow. As such, research needs to be carried out at biologically-relevant scales. Therefore, a crucial first step in understanding responses at the population level will require linking the intra-individual physiology (e.g., transcriptional and cellular responses) to the fitness-related traits of the whole-organism, in order to more reliably estimate the effects of climate change on contemporary population demographics into the future.

\section{Conclusions}

Biotic factors such as competition and trophic interactions shape marine communities at local spatial scales and over relatively short timescales. Other extrinsic factors, such as oceanic and atmospheric environmental conditions will influence patterns of biodiversity over longer timescales, and at regional or global scales [186]. Since climate change is occurring rapidly, it is likely that biotic interactions may play a more important role, compared to abiotic factors, when it comes to evolution (i.e., the Red Queen hypothesis [200]). As such, establishing the association between local environmental conditions and the genomic-physiological features of key species, that are known to be influential in communities (including their interactions with co-existing species), should elucidate how community processes will be affected, and whether evolutionary potential can be realised. However, investigating broader spatial scales will require determining the link between the genomic-physiological responses of contemporary populations and population dynamics. This could establish a deeper understanding between the physiological stress responses of marine organisms to both biotic and abiotic factors, and critical (yet often unknown) demographic processes such as effective population size.

Both adaptation and acclimatisation may enable organisms to persist in future oceans, and understanding how factors at different levels of biological hierarchy will influence these important 
evolutionary responses to climate change is crucial. Future research needs to investigate biological responses both spatially and temporally, by utilising spatially representative replication across different scientific disciplines and research institutes, in an effort to integrate responses and adaptive mechanisms at regional or global scales. This will help to achieve direct comparisons and a more integrative picture of the responses at the community and ecosystem levels. Only then can we establish whether the future organisational structure of marine ecosystems will resemble the communities of today, and what role acclimatisation and adaptation will play in the persistence of marine organisms.

\section{Acknowledgments}

Thanks to Sam Dupont, Piero Calosi, Niall McKeown, Pippa Moore, Paul Shaw, John Spicer and the two anonymous reviewers for their suggestions and feedback that greatly improved this manuscript. The collaboration on this manuscript was made possible due to the CeMEB Advanced Course on Marine Evolution Under Climate Change, funded by the Swedish Royal Academy of Science and organised by Sam Dupont, Piero Calosi, Pierre De Wit, Narimane Dorey, Géraldine Fauville, and Greg "George" Puncher. Funding for Ben Harvey was provided by an Institute of Biological, Environmental and Rural Sciences Ph.D. Studentship and Training Budget. Financial support for Balsam Al-Janabi and Laura S. Stapp was provided by the project BIOACID phase II of the German Federal Ministry of Education and Research (BMBF; FKZ 03F0655A/B), Laura S. Stapp also received a travel grant of the Helmholtz Graduate School for Polar and Marine research (POLMAR). Stefanie Broszeit funded by an assegno di ricerca di Università di Bologna. Amit Kumar and Elena Ricevuto were funded by a PhD Studentship from the Stazione Zoologica Anton Dohrn di Napoli. Funding for Rebekah Cioffi was provided by a Plymouth University Ph.D Studentship. Alison Bailey was provided funding by the Norwegian Research Council and Norwegian Polar Institute. Leon Green participated through funding from the Swedish Royal Academy of Science. Carina M. Gsottbauer was funded by the Integrated Aquatic Resources Management between Ireland, Northern Ireland and Scotland (IBIS) (www.loughs-agency.org/ibis), project 2859 supported by the European Union's Cross-Border Territorial Co-operation Programme for Northern Ireland, the Border Region of Ireland and Western Scotland (INTERREG IVA) programme managed by the Special EU Programmes Body (www.seupb.eu). Emilie Hall had funding provided by the Plymouth University Marine Institute and School of Marine Science \& Engineering University Research Studentship. Maria Lechler was funded by MIUR (Ministero dell'Istruzione, dell'Università e della Ricerca). Francesco P. Mancuso has funding from TETRIS - Observing, modelling and testing synergies and trade-offs for the adaptive management of multiple impacts in coastal systems" (PRIN 2011, Italian Ministry of Education, University and Research). Camila O. Pereira is thankful to FAPESP (Fundação de Amparo à Pesquisa do Estado de São Paulo) for the PhD Scholarship. Research Grant No. 2012/14032-9. Julie B. Schram was funded by the Biology Department, University of Alabama at Birmingham, and travel funding from the Endowed Professorship in Polar and Marine Biology provided to James B. McClintock. Simon Stenberg was supported by the Research Council of Norway, Grant No. 222364/F20. Funding for Lindzai T. Santa Rosa was provided by the Brazilian Agency for Higher Education (Capes). 


\section{Author Contributions}

Original concept, drafting and editing manuscript: Ben Harvey. Group leaders: molecular and cellular responses-Amit Kumar; whole-organism-Rebekah Cioffi; population-level responses-Balsam Al-Janabi; community composition and interactions - Stefanie Broszeit. Figure 1-Ben Harvey. All other authors contributed with concept development, writing and commented on the manuscript at all stages.

\section{Conflicts of Interest}

The authors declare no conflict of interest.

\section{References}

1. Schmitz, O.J. Global climate change and the evolutionary ecology of ecosystem functioning. Annu. N. Y. Acad. Sci. 2013, 1297, 61-72.

2. Bell, G.; Gonzalez, A. Evolutionary rescue can prevent extinction following environmental change. Ecol. Lett. 2009, 12, 942-948.

3. Burrows, M.T.; Schoeman, D.S.; Buckley, L.B.; Moore, P.; Poloczanska, E.S.; Brander, K.M.; Brown, C.; Bruno, J.F.; Duarte, C.M.; Halpern, B.S.; et al. The pace of shifting climate in marine and terrestrial ecosystems. Science 2011, 334, 652-655.

4. Doney, S.C.; Schimel, D.S. Carbon and climate system coupling on timescales from the precambrian to the anthropocene. Annu. Rev. Environ. Resour. 2007, 32, 31-66.

5. Halpern, B.S.; Walbridge, S.; Selkoe, K.A.; Kappel, C.V.; Micheli, F.; D’Agrosa, C.; Bruno, J.F.; Casey, K.S.; Ebert, C.; Fox, H.E.; et al. A global map of human impact on marine ecosystems. Science 2008, 319, 948-952.

6. Dupont, S.; Dorey, N.; Thorndyke, M. What meta-analysis can tell us about vulnerability of marine biodiversity to ocean acidification? Estuar. Coast. Shelf Sci. 2010, 89, 182-185.

7. Kroeker, K.; Kordas, R.; Crim, R.; Singh, G. Meta-analysis reveals negative yet variable effects of ocean acidification on marine organisms. Ecol. Lett. 2010, 13, 1419-1434.

8. Harvey, B.P.; Gwynn-Jones, D.; Moore, P.J. Meta-analysis reveals complex marine biological responses to the interactive effects of ocean acidification and warming. Ecol. Evol. 2013, 3, 1016-1030.

9. Kroeker, K.J.; Kordas, R.L.; Crim, R.; Hendriks, I.E.; Ramajo, L.; Singh, G.S.; Duarte, C.M.; Gattuso, J.-P. Impacts of ocean acidification on marine organisms: Quantifying sensitivities and interaction with warming. Glob. Change Biol. 2013, 19, 1884-1896.

10. Pörtner, H.-O. Physiological basis of temperature-dependent biogeography: Trade-offs in muscle design and performance in polar ectotherms. J. Exp. Biol. 2002, 205, 2217-2230.

11. Somero, G.N. Linking biogeography to physiology: Evolutionary and acclimatory adjustments of thermal limits. Front. Zool. 2005, 2, 1.

12. Widdicombe, S.; Spicer, J. Predicting the impact of ocean acidification on benthic biodiversity: What can animal physiology tell us? J. Exp. Mar. Biol. Ecol. 2008, 366, 187-197.

13. Somero, G.N. The physiology of climate change: How potentials for acclimatization and genetic adaptation will determine 'winners' and 'losers'. J. Exp. Biol. 2010, 213, 912-920. 
14. Van der Putten, W.H.; Macel, M.; Visser, M.E. Predicting species distribution and abundance responses to climate change: Why it is essential to include biotic interactions across trophic levels. Philos. Trans. R. Soc. Lond. B Biol. Sci. 2010, 365, 2025-2034.

15. Stockwell, C.A.; Hendry, A.P.; Kinnison, M.T. Contemporary evolution meets conservation biology. Trends Ecol. Evol. 2003, 18, 94-101.

16. Munday, P.L.; Warner, R.R.; Monro, K.; Pandolfi, J.M.; Marshall, D.J. Predicting evolutionary responses to climate change in the sea. Ecol. Lett. 2013, 16, 1488-1500.

17. Sunday, J.M.; Calosi, P.; Dupont, S.; Munday, P.L.; Stillman, J.H.; Reusch, T.B.H. Evolution in an acidifying ocean. Trends Ecol. Evol. 2014, 29, 117-125.

18. Dupont, S.; Portner, H. Marine science: Get ready for ocean acidification. Nature 2013, 498, 429.

19. Gienapp, P.; Teplitsky, C.; Alho, J.S.; Mills, J.A.; Merilä, J. Climate change and evolution: Disentangling environmental and genetic responses. Mol. Ecol. 2008, 17, 167-178.

20. Merilä, J.; Hendry, A.P. Climate change, adaptation, and phenotypic plasticity: The problem and the evidence. Evol. Appl. 2014, 7, 1-14.

21. Chevin, L.-M.; Lande, R.; Mace, G.M. Adaptation, plasticity, and extinction in a changing environment: Towards a predictive theory. PLoS Biol. 2010, 8, doi:10.1371/journal.pbio.1000357.

22. Hoffmann, A.A.; Sgrò, C.M. Climate change and evolutionary adaptation. Nature 2011, 470, 479-485.

23. Reusch, T.B.H. Climate change in the oceans: Evolutionary versus phenotypically plastic responses of marine animals and plants. Evol. Appl. 2013, 7, 104-122.

24. Blondel, J. From biogeography to life history theory: A multithematic approach illustrated by the biogeography of vertebrates. J. Biogeogr. 1987, 14, 405-422.

25. Palumbi, S.R.; Barshis, D.J.; Traylor-Knowles, N.; Bay, R.A. Mechanisms of reef coral resistance to future climate change. Science 2014, 344, 895-898.

26. Calosi, P.; Rastrick, S.P.S.; Lombardi, C.; de Guzman, H.J.; Davidson, L.; Jahnke, M.; Giangrande, A.; Hardege, J.D.; Schulze, A.; Spicer, J.I.; et al. Adaptation and acclimatization to ocean acidification in marine ectotherms: An in situ transplant experiment with polychaetes at a shallow $\mathrm{CO}_{2}$ vent system. Philos. Trans. R. Soc. Lond. B Biol. Sci. 2013, 368, doi: 10.1098/rstb.2012.0444.

27. Queirós, A.M.; Fernandes, J.A.; Faulwetter, S.; Nunes, J.; Rastrick, S.P.S.; Mieszkowska, N.; Artioli, Y.; Yool, A.; Calosi, P.; Arvanitidis, C.; et al. Scaling up experimental ocean acidification and warming research: From individuals to the ecosystem. Glob. Change Biol. 2014, doi:10.1111/gcb.12675.

28. Prosser, C.L. Physiological variation in animals. Biol. Rev. 1955, 30, 229-261.

29. Somero, G.N. The physiology of global change: Linking patterns to mechanisms. Annu. Rev. Mar. Sci. 2012, 4, 39-61.

30. Feder, M.E.; Walser, J.C. The biological limitations of transcriptomics in elucidating stress and stress responses. J. Evol. Biol. 2005, 18, 901-910.

31. Berg, J.M.; Tymoczko, J.L.; Stryer, L. Biochemistry; WH Freeman: New York, NY, USA, 2002; p. 1026.

32. Griffiths, A.J.F.; Miller, J.H.; Suzuki, D.T.; Lewontin, R.C.; Gelbart, W.M. Gene-protein relations. In An Introduction to Genetic Analysis, 7th ed.; Griffiths, A.J.F., Ed.; WH Freeman: New York, NY, USA, 2000. 
33. Kassahn, K.S.; Crozier, R.H.; Pörtner, H.O.; Caley, M.J. Animal performance and stress: Responses and tolerance limits at different levels of biological organisation. Biol. Rev. Camb. Philos. Soc. 2009, 84, 277-292.

34. Fields, P.A.; Rudomin, E.L.; Somero, G.N. Temperature sensitivities of cytosolic malate dehydrogenases from native and invasive species of marine mussels (genus Mytilus): Sequence-function linkages and correlations with biogeographic distribution. J. Exp. Biol. 2006, 209, 656-667.

35. Powers, D.A.; Schulte, P.M. Evolutionary adaptations of gene structure and expression in natural populations in relation to a changing environment: A multidisciplinary approach to address the million-year saga of a small fish. J. Exp. Zool. 1998, 282, 71-94.

36. Norry, F.M.; Larsen, P.F.; Liu, Y.; Loeschcke, V. Combined expression patterns of QTL-linked candidate genes best predict thermotolerance in Drosophila melanogaster. J. Insect Physiol. 2009, $55,1050-1057$.

37. Franks, S.J.; Hoffmann, A.A. Genetics of climate change adaptation. Annu. Rev. Genet. 2012, 46, 185-208.

38. Davidson, E.H. The Regulatory Genome: Gene Regulatory Networks in Development and Evolution; Academic Press: San Diego, CA, USA, 2006.

39. Davidson, E.; Levin, M. Gene regulatory networks. Proc. Natl. Acad. Sci. USA 2005, 102, 4935.

40. Williams, S.E.; Shoo, L.P.; Isaac, J.L.; Hoffmann, A.A.; Langham, G. Towards an integrated framework for assessing the vulnerability of species to climate change. PLoS Biol. 2008, 6, e325.

41. Bradshaw, W.E.; Holzapfel, C.M. Light, time, and the physiology of biotic response to rapid climate change in animals. Annu. Rev. Physiol. 2010, 72, 147-166.

42. Atkinson, N.J.; Urwin, P.E. The interaction of plant biotic and abiotic stresses: From genes to the field. J. Exp. Bot. 2012, 63, 3523-3543.

43. Gardner, J.L.; Peters, A.; Kearney, M.R.; Joseph, L.; Heinsohn, R. Declining body size: A third universal response to warming? Trends Ecol. Evol. 2011, 26, 285-291.

44. Kovach, R.P.; Gharrett, A.J.; Tallmon, D.A. Genetic change for earlier migration timing in a pink salmon population. Proc. R. Soc. Biol. Sci. Ser. B 2012, 279, 3870-3878.

45. Karell, P.; Ahola, K.; Karstinen, T.; Valkama, J.; Brommer, J.E. Climate change drives microevolution in a wild bird. Nat. Commun. 2011, 2, 208.

46. Runcie, D.E.; Garfield, D.A.; Babbitt, C.C.; Wygoda, J.A.; Mukherjee, S.; Wray, G.A. Genetics of gene expression responses to temperature stress in a sea urchin gene network. Mol. Ecol. 2012, $21,4547-4562$.

47. Keller, B.; Feuillet, C. Colinearity and gene density in grass genomes. Trends Plant Sci. 2000, 5, 246-251.

48. Barshis, D.J.; Ladner, J.T.; Oliver, T.A.; Seneca, F.O.; Traylor-Knowles, N.; Palumbi, S.R. Genomic basis for coral resilience to climate change. Proc. Natl. Acad. Sci. USA 2013, 110, 1387-1392.

49. Todgham, A.E.; Hofmann, G.E. Transcriptomic response of sea urchin larvae Strongylocentrotus purpuratus to $\mathrm{CO}_{2}$-driven seawater acidification. J. Exp. Biol. 2009, 212, 2579-2594.

50. Wray, G.A. The evolutionary significance of cis-regulatory mutations. Nat. Rev. Genet. 2007, 8, 206-216. 
51. Barrett, R.D.; Hoekstra, H.E. Molecular spandrels: Tests of adaptation at the genetic level. Nat. Rev. Genet. 2011, 12, 767-780.

52. Davidson, W.S. Adaptation genomics: next generation sequencing reveals a shared haplotype for rapid early development in geographically and genetically distant populations of rainbow trout. Mol. Ecol. 2012, 21, 219-222.

53. Edwards, S.V. Next-generation QTL mapping: Crowdsourcing SNPs, without pedigrees. Mol. Ecol. 2013, 22, 3885-3887.

54. Kaniewska, P.; Campbell, P.R.; Kline, D.I.; Rodriguez-Lanetty, M.; Miller, D.J.; Dove, S.; Hoegh-Guldberg, O. Major cellular and physiological impacts of ocean acidification on a reef building coral. PLOS ONE 2012, 7, e34659.

55. Sokolova, I.M.; Frederich, M.; Bagwe, R.; Lannig, G.; Sukhotin, A.A. Energy homeostasis as an integrative tool for assessing limits of environmental stress tolerance in aquatic invertebrates. Mar. Environ. Res. 2012, 79, 1-15.

56. Seebacher, F.; Franklin, C.E. Determining environmental causes of biological effects: The need for a mechanistic physiological dimension in conservation biology. Philos. Trans. R. Soc. Lond. B Biol. Sci. 2012, 367, 1607-1614.

57. Buckley, B.A.; Gracey, A.Y.; Somero, G.N. The cellular response to heat stress in the goby Gillichthys mirabilis: A cDNA microarray and protein-level analysis. J. Exp. Biol. 2006, 209, 2660-2677.

58. Wapinski, I.; Pfeffer, A.; Friedman, N.; Regev, A., Natural history and evolutionary principles of gene duplication in fungi. Nature 2007, 449, 54-61.

59. Raffaele, S.; Farrer, R.A.; Cano, L.M.; Studholme, D.J.; MacLean, D.; Thines, M.; Jiang, R.H.Y.; Zody, M.C.; Kunjeti, S.G.; Donofrio, N.M.; et al. Genome evolution following host jumps in the Irish potato famine pathogen lineage. Science 2010, 330, 1540-1543.

60. Hartl, D.L. Essential Genetics: A Genomics Perspective; Jones and Bartlett Publishers: London, UK, 2014.

61. Pires-daSilva, A.; Sommer, R.J. The evolution of signalling pathways in animal development. Nat. Rev. Genet. 2003, 4, 39-49.

62. Garcia-Moreno, B. Adaptations of proteins to cellular and subcellular pH. J. Biol. 2009, 8, 98.

63. Salinas, S.; Munch, S.B. Thermal legacies: transgenerational effects of temperature on growth in a vertebrate. Ecol. Lett. 2012, 15, 159-163.

64. Jaenisch, R.; Bird, A. Epigenetic regulation of gene expression: How the genome integrates intrinsic and environmental signals. Nat. Genet. 2003, 33, 245-254.

65. Turner, B.M. Epigenetic responses to environmental change and their evolutionary implications. Philos. Trans. R. Soc. B Biol. Sci. 2009, 364, 3403-3418.

66. Parker, L.M.; Ross, P.M.; O’Connor, W.A.; Borysko, L.; Raftos, D.A.; Pörtner, H.-O. Adult exposure influences offspring response to ocean acidification in oysters. Glob. Change Biol. 2012, 18, 82-92.

67. Garfield, D.A.; Runcie, D.E.; Babbitt, C.C.; Haygood, R.; Nielsen, W.J.; Wray, G.A. The Impact of gene expression variation on the robustness and evolvability of a developmental Gene Regulatory Network. PLoS Biol. 2013, 11, doi:10.1371/journal.pbio.1001696.

68. Suchanek, T.H. The role of disturbance in the evolution of life history strategies in the intertidal mussels Mytilus edulis and Mytilus californianus. Oecologia 1981, 50, 143-152. 
69. Dawson, M.N. Phylogeography in coastal marine animals: A solution from California? J. Biogeogr. 2001, 28, 723-736.

70. Sherman, C.D.H.; Hunt, A.; Ayre, D.J. Is life history a barrier to dispersal? Contrasting patterns of genetic differentiation along an oceanographically complex coast. Biol. J. Linn. Soc. 2008, 95, 106-116.

71. Sunday, J.M.; Crim, R.N.; Harley, C.D.G.; Hart, M.W. Quantifying rates of evolutionary adaptation in response to ocean acidification. PLOS ONE 2011, 6, e22881.

72. Brown, J.H.; Gillooly, J.F.; Allen, A.P.; Savage, V.M.; West, G.B. Toward a metabolic theory of ecology. Ecology 2004, 85, 1771-1789.

73. Kooijman, S.A.L.M. Dynamic Energy Budget Theory for Metabolic Organisation; Cambridge University Press: Cambridge, UK, 2010; p. 514.

74. Holcomb M.; McCorkle D.C.; Cohen A.L. Long-term effects of nutrient and $\mathrm{CO}_{2}$ enrichment on the temperate coral astrangia poculata (Ellis and Solander, 1786). J. Exp. Mar. Biol. Ecol. 2010, 386, 27-33.

75. Foo, S.A.; Dworjanyn, S.A.; Poore, A.G.B.; Byrne, M. Adaptive capacity of the habitat modifying sea urchin Centrostephanus rodgersii to ocean warming and ocean acidification: Performance of early embryos. PLoS ONE 2012, 7, e42497.

76. Langenbuch, M.; Pörtner, H.O. High sensitivity to chronically elevated $\mathrm{CO}_{2}$ levels in a eurybathic marine sipunculid. Aquat. Toxicol. 2004, 70, 55-61.

77. Kurihara, $\mathrm{H}$. Effects of $\mathrm{CO}_{2}$-driven ocean acidification on the early developmental stages of invertebrates. Mar. Ecol. Prog. Ser. 2008, 373, 275-284.

78. Pörtner, H.-O. Ecosystem effects of ocean acidification in times of ocean warming: A physiologist's view. Mar. Ecol. Prog. Ser. 2008, 373, 203-217.

79. O'Connor, M.I.; Bruno, J.F.; Gaines, S.D.; Halpern, B.S.; Lester, S.E.; Kinlan, B.P.; Weiss, J.M. Temperature control of larval dispersal and the implications for marine ecology, evolution, and conservation. Proc. Natl. Acad. Sci. USA 2007, 104, 1266-1271.

80. Arnold, K.; Findlay, H.; Spicer, J.; Daniels, C.; Boothroyd, D. Effect of $\mathrm{CO}_{2}$-related acidification on aspects of the larval development of the European lobster, Homarus gammarus (L.). Biogeosciences 2009, 6, 1747-1754.

81. McDonald, M.R.; McClintock, J.B.; Amsler, C.D.; Rittschof, D.; Angus, R.A.; Orihuela, B.; Lutostanski, K. Effects of ocean acidification over the life history of the barnacle Amphibalanus amphitrite. Mar. Ecol. Prog. Ser. 2009, 385, 179-187.

82. Byrne, M. Impact of ocean warming and ocean acidification on marine invertebrate life history stages: Vulnerabilities and potential for persistence in a changing ocean. Oceanogr. Mar. Biol. 2011, 49, 1-42.

83. Miller, N.A.; Paganini, A.W.; Stillman, J.H. Differential thermal tolerance and energetic trajectories during ontogeny in porcelain crabs, genus Petrolisthes. J. Therm. Biol. 2013, 38, 79-85.

84. Emlet, R.B.; Sadro, S.S. Linking stages of life history: How larval quality translates into juvenile performance for an intertidal barnacle (Balanus glandula). Integr. Comp. Biol. 2006, 46, 334-346.

85. Werner, E.E.; Gilliam, J.F. The ontogenetic niche and species interactions in size-structured populations. Annu. Rev. Ecol. Syst. 1984, 15, 393-425. 
86. Dupont, S.; Dorey, N.; Stumpp, M.; Melzner, F.; Thorndyke, M.C. Long-term and trans-life-cycle effects of exposure to ocean acidification in the green sea urchin Strongylocentrotus droebachiensis. Mar. Biol. 2012, 160, 1835-1843.

87. Ferrari, M.C.O.; Manassa, R.P.; Dixson, D.L.; Munday, P.L.; McCormick, M.I.; Meekan, M.G.; Sih, A.; Chivers, D.P. Effects of ocean acidification on learning in coral reef fishes. PLoS ONE 2012, 7, e31478.

88. Candolin, U.; Wong, B.B.M. Behavioural Responses to a Changing World: Mechanisms and Consequences; Oxford University Press: Oxford, UK, 2012; pp. 208-210.

89. Dissanayake, A.; Ishimatsu, A. Synergistic effects of elevated $\mathrm{CO}_{2}$ and temperature on the metabolic scope and activity in a shallow-water coastal decapod (Metapenaeus joyneri; Crustacea: Penaeidae). ICES J. Mar. Sci. 2011, 68, 1147-1154.

90. Biro, P.A.; Beckmann, C.; Stamps, J.A. Small within-day increases in temperature affects boldness and alters personality in coral reef fish. Proc. R. Soc. Biol. Sci. B 2010, 277, 71-77.

91. Watson, S.-A.; Lefevre, S.; McCormick, M.I.; Domenici, P.; Nilsson, G.E.; Munday, P.L. Marine mollusc predator-escape behaviour altered by near-future carbon dioxide levels. Proc. $R$. Soc. Biol. Sci. B 2014, 281, doi: 10.1098/rspb.2013.2377.

92. Nilsson, G.E.; Dixson, D.L.; Domenici, P.; McCormick, M.I.; Sørensen, C.; Watson, S.-A.; Munday, P.L. Near-future carbon dioxide levels alter fish behaviour by interfering with neurotransmitter function. Nat. Clim. Change 2012, 2, 201-204.

93. Chivers, D.P.; McCormick, M.I.; Nilsson, G.E.; Munday, P.L.; Watson, S.-A.; Meekan, M.G.; Mitchell, M.D.; Corkill, K.C.; Ferrari, M.C.O. Impaired learning of predators and lower prey survival under elevated $\mathrm{CO}_{2}$ : A consequence of neurotransmitter interference. Glob. Change Biol. 2014, 20, 515-522.

94. Munday, P.L.; Dixson, D.L.; Donelson, J.M.; Jones, G.P.; Pratchett, M.S.; Devitsina, G.V.; Døving, K.B. Ocean acidification impairs olfactory discrimination and homing ability of a marine fish. Proc. Natl. Acad. Sci. USA 2009, 106, 1848.

95. Goh, C.S.; Bogan, A.A.; Joachimiak, M.; Walther, D.; Cohen, F.E. Co-evolution of proteins with their interaction partners. J. Mol. Biol. 2000, 299, 283-293.

96. Greenwood, A.K.; Wark, A.R.; Yoshida, K.; Peichel, C.L. Genetic and neural modularity underlie the evolution of schooling behavior in threespine sticklebacks. Curr. Biol. 2013, 23, 1884-1888.

97. Blomberg, S.P.; Garland, T.; Ives, A.R. Testing for phylogenetic signal in comparative data: Behavioral traits are more labile. Evolution 2003, 57, 717-745.

98. Bradshaw, A.D.; McNeilly, T. Evolutionary response to global climatic change. Ann. Bot. Lond. 1991, 67, 5-14.

99. Bohonak, A.J. Dispersal, gene flow, and population structure. Q. Rev. Biol. 1999, 74, 21-45.

100. Hellberg, M.E.; Burton, R.S.; Neigel, J.E.; Palumbi, S.R. Genetic assessment of connectivity among marine populations. Bull. Mar. Sci. 2002, 70, 273-290.

101. Sanford, E.; Kelly, M.W. Local adaptation in marine invertebrates. Ann. Rev. Mar. Sci. 2011, 3, 509-535.

102. Merilä, J. Evolution in response to climate change: In pursuit of the missing evidence. BioEssays 2012, 34, 811-818. 
103. Gonzalez, A.; Ronce, O.; Ferriere, R.; Hochberg, M.E. Evolutionary rescue: An emerging focus at the intersection between ecology and evolution. Philos. Trans. R. Soc. Lond. B Biol. Sci. 2013, 368, doi:10.1098/rstb.2012.0404.

104. Johannesson, K.; Smolarz, K.; Grahn, M.; André, C. The future of Baltic Sea populations: Local extinction or evolutionary rescue? Ambio 2011, 40, 179-190.

105. Bell, G. Evolutionary rescue and the limits of adaptation. Philos. Trans. R. Soc. Lond. B Biol. Sci. 2013, 368, doi:10.1098/rstb.2012.0080.

106. Cuveliers, E.L.; Volckaert, F.A.M.; Rijnsdorp, A.D.; Larmuseau, M.H.D.; Maes, G.E. Temporal genetic stability and high effective population size despite fisheries-induced life-history trait evolution in the North Sea sole. Mol. Ecol. 2011, 20, 3555-3568.

107. Reusch, T.B.H.; Ehlers, A.; Hämmerli, A.; Worm, B. Ecosystem recovery after climatic extremes enhanced by genotypic diversity. Proc. Natl. Acad. Sci. USA 2005, 102, 2826-2831.

108. Lohbeck, K.T.; Riebesell, U.; Reusch, T.B.H. Adaptive evolution of a key phytoplankton species to ocean acidification. Nat. Geosci. 2012, 5, 346-351.

109. Jin, P.; Gao, K.; Beardall, J. Evolutionary responses of a coccolithophorid Gephyrocapsa oceanica to ocean acidification. Evolution 2013, 67, 1869-1878.

110. Crawfurd, K.J.; Raven, J.A.; Wheeler, G.L.; Baxter, E.J.; Joint, I. The response of Thalassiosira pseudonana to long-term exposure to increased $\mathrm{CO}_{2}$ and decreased pH. PLOS ONE 2011, 6, e26695.

111. Smith-Keune, C.; Oppen, M. Genetic structure of a reef-building coral from thermally distinct environments on the Great Barrier Reef. Coral Reefs 2006, 25, 493-502.

112. D'Croz, L.; Maté, J.L. Experimental responses to elevated water temperature in genotypes of the reef coral Pocillopora damicornis from upwelling and non-upwelling environments in Panama. Coral Reefs 2004, 23, 473-483.

113. Yanick, J.F.; Heath, J.W.; Heath, D.D. Survival and growth of local and transplanted blue mussels (Mytilus trossulus, Lamark). Aquac. Res. 2003, 34, 869-875.

114. De Wit, P.; Palumbi, S.R. Transcriptome-wide polymorphisms of red abalone (Haliotis rufescens) reveal patterns of gene flow and local adaptation. Mol. Ecol. 2013, 22, 2884-2897.

115. Gaston, K.J.; Spicer, J.I. Do upper thermal tolerances differ in geographically separated populations of the beachflea Orchestia gammarellus (Crustacea: Amphipoda)? J. Exp. Mar. Biol. Ecol. 1998, 229, 265-276.

116. Schmidt, C.; Heinz, P.; Kucera, M.; Uthicke, S. Temperature-induced stress leads to bleaching in larger benthic foraminifera hosting endosymbiotic diatoms. Limnol. Oceanogr. 2011, 56, 1587-1602.

117. Kelly, M.W.; Sanford, E.; Grosberg, R.K. Limited potential for adaptation to climate change in a broadly distributed marine crustacean. Proc. R. Soc. Biol. Sci. B 2012, 279, 349-356.

118. Sanford, E.; Holzman, S.B.; Haney, R.A.; Rand, D.M.; Bertness, M.D. Larval tolerance, gene flow, and the northern geographic range limit of fiddler crabs. Ecology 2006, 87, 2882-2894.

119. Lymbery, R.A.; Evans, J.P. Genetic variation underlies temperature tolerance of embryos in the sea urchin Heliocidaris erythrogramma armigera. J. Evol. Biol. 2013, 26, 2271-2282.

120. Osovitz, C.J.; Hofmann, G.E. Thermal history-dependent expression of the $h s p 70$ gene in purple sea urchins: Biogeographic patterns and the effect of temperature acclimation. J. Exp. Mar. Biol. Ecol. 2005, 327, 134-143. 
121. Kelly, M.W.; Padilla-Gamiño, J.L.; Hofmann, G.E. Natural variation and the capacity to adapt to ocean acidification in the keystone sea urchin Strongylocentrotus purpuratus. Glob. Change Biol. 2013, 19, 2536-2546.

122. Pecorino, D.; Barker, M.F.; Dworjanyn, S.A.; Byrne, M.; Lamare, M.D. Impacts of near future sea surface $\mathrm{pH}$ and temperature conditions on fertilisation and embryonic development in Centrostephanus rodgersii from northern New Zealand and northern New South Wales, Australia. Mar. Biol. 2014, 161, 101-110.

123. Marcil, J.; Swain, D.P.; Hutchings, J.A. Countergradient variation in body shape between two populations of Atlantic cod (Gadus morhua). Proc. R. Soc. Biol. Sci. B 2006, 273, 217-223.

124. Fangue, N.A.; Hofmeister, M.; Schulte, P.M. Intraspecific variation in thermal tolerance and heat shock protein gene expression in common killifish, Fundulus heteroclitus. J. Exp. Biol. 2006, 209, 2859-2872.

125. Schaum, E.; Rost, B.; Millar, A.J.; Collins, S. Variation in plastic responses of a globally distributed picoplankton species to ocean acidification. Nature Clim. Change 2012, 3, 298-302.

126. Pistevos, J.C.A.; Calosi, P.; Widdicombe, S.; Bishop, J.D.D. Will variation among genetic individuals influence species responses to global climate change? Oikos 2011, 120, 675-689.

127. Willi, Y.; Van Buskirk, J.; Hoffmann, A.A. Limits to the adaptive potential of small populations. Annu. Rev. Ecol. Evol. Syst. 2006, 37, 433-458.

128. Lande, R. Adaptation to an extraordinary environment by evolution of phenotypic plasticity and genetic assimilation. J. Evol. Biol. 2009, 22, 1435-1446.

129. Feely, R.A.; Sabine, C.L.; Hernandez-Ayon, J.M.; Ianson, D.; Hales, B. Evidence for upwelling of corrosive "acidified" water onto the continental shelf. Science 2008, 320, 1490-1492.

130. Evans, T.G.; Chan, F.; Menge, B.A.; Hofmann, G.E. Transcriptomic responses to ocean acidification in larval sea urchins from a naturally variable pH environment. Mol. Ecol. 2013, 22, 1609-1625.

131. Saderne, V.; Wahl, M. Differential responses of calcifying and non-calcifying epibionts of a brown macroalga to present-day and future upwelling $p \mathrm{CO}_{2}$. PLoS ONE 2013, 8, e70455.

132. Leal, S.M. Genetics and Analysis of Quantitative Traits. Am. J. Hum. Genet. 2001, 68, 548-549.

133. Hughes, A.R.; Inouye, B.D.; Johnson, M.T.J.; Underwood, N.; Vellend, M. Ecological consequences of genetic diversity. Ecol. Lett. 2008, 11, 609-623.

134. Pespeni, M.H.; Sanford, E.; Gaylord, B.; Hill, T.M.; Hosfelt, J.D.; Jaris, H.K.; LaVigne, M.; Lenz, E.A.; Russell, A.D.; Young, M.K.; et al. Evolutionary change during experimental ocean acidification. Proc. Natl. Acad. Sci. USA 2013, 110, 6937-6942.

135. Hedrick, P.W. Genetic Polymorphism in Heterogeneous Environments: The Age of Genomics. Annu. Rev. Ecol., Evol., Syst. 2006, 37, 67-93.

136. Intergovernmental Panel on Climate Change. Climate Change 2013-The Physical Science Basis; Cambridge University Press: Cambridge, UK, 2014.

137. Thomsen, J.; Casties, I.; Pansch, C.; Körtzinger, A.; Melzner, F. Food availability outweighs ocean acidification effects in juvenile Mytilus edulis: Laboratory and field experiments. Glob. Change Biol. 2012, 19, 1017-1027. 
138. Thomsen, J.; Gutowska, M.A.; Saphörster, J.; Heinemann, A.; Trübenbach, K.; Fietzke, J.; Hiebenthal, C.; Eisenhauer, A.; Körtzinger, A.; Wahl, M.; et al. Calcifying invertebrates succeed in a naturally $\mathrm{CO}_{2}$-rich coastal habitat but are threatened by high levels of future acidification. Biogeosciences 2010, 7, 3879-3891.

139. Dam, H.G. Evolutionary adaptation of marine zooplankton to global change. Annu. Rev. Mar. Sci. 2013, 5, 349-370.

140. Conover, D.O.; Present, T.M.C. Countergradient variation in growth rate: Compensation for length of the growing season among Atlantic silversides from different latitudes. Oecologia 1990, 83, 316-324.

141. Hairston, N.G.; Ellner, S.P.; Geber, M.A.; Yoshida, T.; Fox, J.A. Rapid evolution and the convergence of ecological and evolutionary time. Ecol. Lett. 2005, 8, 1114-1127.

142. Olsen, E.M.; Heino, M.; Lilly, G.R.; Morgan, M.J.; Brattey, J.; Ernande, B.; Dieckmann, U. Maturation trends indicative of rapid evolution preceded the collapse of northern cod. Nature 2004, 428, 932-935.

143. Schoener, T.W. The newest synthesis: understanding the interplay of evolutionary and ecological dynamics. Science 2011, 331, 426-429.

144. Palkovacs, E.P.; Marshall, M.C.; Lamphere, B.A.; Lynch, B.R.; Weese, D.J.; Fraser, D.F.; Reznick, D.N.; Pringle, C.M.; Kinnison, M.T. Experimental evaluation of evolution and coevolution as agents of ecosystem change in Trinidadian streams. Philos. Trans. R. Soc. B 2009, 364, 1617-1628.

145. Janzen, D.H. When is it coevolution. Evolution 1980, 34, 611-612.

146. Turcotte, M.M.; Corrin, M.S.; Johnson, M.T. Adaptive evolution in ecological communities. PLoS Biol. 2012, 10, doi:10.1371/journal.pbio.1001332.

147. Strauss, S.Y.; Sahli, H.; Conner, J.K. Toward a more trait-centered approach to diffuse (co)evolution. New Phytol. 2005, 165, 81-89.

148. Lai, S.-M.; Liu, W.-C.; Jordán, F. On the centrality and uniqueness of species from the network perspective. Biol. Lett. 2012, 8, 570-573.

149. Hale, R.; Calosi, P.; McNeill, L.; Mieszkowska, N.; Widdicombe, S. Predicted levels of future ocean acidification and temperature rise could alter community structure and biodiversity in marine benthic communities. Oikos 2011, 120, 661-674.

150. Diaz-Pulido, G.; Gouezo, M.; Tilbrook, B.; Dove, S.; Anthony, K. High $\mathrm{CO}_{2}$ enhances the competitive strength of seaweeds over corals. Ecol. Lett. 2011, 14, 156-162.

151. Ferrari, M.C.O.; McCormick, M.I.; Munday, P.L.; Meekan, M.G.; Dixson, D.L.; Lonnstedt, Ö.; Chivers, D.P. Putting prey and predator into the $\mathrm{CO}_{2}$ equation-Qualitative and quantitative effects of ocean acidification on predator-prey interactions. Ecol. Lett. 2011, 14, 1143-1148.

152. Sanford, E.; Gaylord, B.; Hettinger, A.; Lenz, E.A.; Meyer, K.; Hill, T.M. Ocean acidification increases the vulnerability of native oysters to predation by invasive snails. Proc. R. Soc. Biol. Sci. B 2014, 281, doi: 10.1098/rspb.2013.2681.

153. O'Connor, M.I. Warming strengthens an herbivore-plant interaction. Ecology 2009, 90, 388-398.

154. Poore, A.G.B.; Graba-Landry, A.; Favret, M.; Sheppard Brennand, H.; Byrne, M.; Dworjanyn, S.A. Direct and indirect effects of ocean acidification and warming on a marine plantherbivore interaction. Oecologia 2013, 173, 1113-1124. 
155. Collins, S.; Rost, B.; Rynearson, T.A. Evolutionary potential of marine phytoplankton under ocean acidification. Evol. Appl. 2014, 7, 140-155.

156. Falkowski, P.G.; Fenchel, T.; Delong, E.F. The microbial engines that drive Earth's biogeochemical cycles. Science 2008, 320, 1034-1039.

157. Iglesias-Rodriguez, M.; Halloran, P.; Rickaby, R.; Hall, I.; Colmenero-Hidalgo, E.; Gittins, J.; Green, D.; Tyrrell, T.; Gibbs, S.; von Dassow, P.; et al. Phytoplankton calcification in a high- $\mathrm{CO}_{2}$ world. Science 2008, 320, 336-340.

158. Harley, C.D.G.; Anderson, K.M.; Demes, K.W.; Jorve, J.P.; Kordas, R.L.; Coyle, T.A.; Graham, M.H. Effects of climate change on global seaweed communities. J. Phycol. 2012, 48, 1064-1078.

159. Hurd, C.L.; Hepburn, C.D.; Currie, K.I.; Raven, J.A.; Hunter, K.A. Testing the effects of ocean acidification on algal metabolism: Considerations for experimental designs. J. Phycol. 2009, 45, 1236-1251.

160. Tatters, A.O.; Schnetzer, A.; Fu, F.; Lie, A.Y.A.; Caron, D.A.; Hutchins, D.A. Short- versus long-term responses to changing $\mathrm{CO}_{2}$ in a coastal dinoflagellate bloom: Implications for interspecific competitive interactions and community structure. Evolution 2013, 67, 1879-1891.

161. Kremp, A.; Godhe, A.; Egardt, J.; Dupont, S.; Suikkanen, S.; Casabianca, S.; Penna, A. Intraspecific variability in the response of bloom-forming marine microalgae to changed climate conditions. Ecol. Evol. 2012, 2, 1195-1207.

162. Boyd, P.W.; Rynearson, T.A.; Armstrong, E.A.; Fu, F.; Hayashi, K.; Hu, Z.; Hutchins, D.A.; Kudela, R.M.; Litchman, E.; Mulholland, M.R.; et al. Marine phytoplankton temperature versus growth responses from polar to tropical waters-Outcome of a scientific community-wide study. PLoS ONE 2013, 8, e63091.

163. Alsterberg, C.; Eklöf, J.S.; Gamfeldt, L.; Havenhand, J.N.; Sundbäck, K. Consumers mediate the effects of experimental ocean acidification and warming on primary producers. Proc. Natl. Acad. Sci. USA 2013, 110, 8603-8608.

164. Witt, V.; Wild, C.; Anthony, K.R.N.; Diaz-Pulido, G.; Uthicke, S. Effects of ocean acidification on microbial community composition of, and oxygen fluxes through, biofilms from the Great Barrier Reef. Environ. Microbiol. 2011, 13, 2976-2989.

165. Beaugrand, G.; Brander, K.M.; Alistair Lindley, J.; Souissi, S.; Reid, P.C. Plankton effect on cod recruitment in the North Sea. Nature 2003, 426, 661-664.

166. Melzner, F.; Stange, P.; Trübenbach, K.; Thomsen, J.; Casties, I.; Panknin, U.; Gorb, S.N.; Gutowska, M.A. Food supply and seawater $p \mathrm{CO}_{2}$ impact calcification and internal shell dissolution in the blue mussel Mytilus edulis. PLoS ONE 2011, 6, e24223.

167. Calosi, P.; Rastrick, S.P.S.; Graziano, M.; Thomas, S.C.; Baggini, C.; Carter, H.A.; Hall-Spencer, J.M.; Milazzo, M.; Spicer, J.I. Distribution of sea urchins living near shallow water $\mathrm{CO}_{2}$ vents is dependent upon species acid-base and ion-regulatory abilities. Mar. Pollut. Bull. 2013, 73, 470-484.

168. Connell, S.D.; Kroeker, K.J.; Fabricius, K.E.; Kline, D.I.; Russell, B.D. The other ocean acidification problem: $\mathrm{CO}_{2}$ as a resource among competitors for ecosystem dominance. Philos. Trans. R. Soc. Lond. B Biol. Sci. 2013, 368, doi:10.1098/rstb.2012.0442. 
169. Kroeker, K.J.; Micheli, F.; Gambi, M.C. Ocean acidification causes ecosystem shifts via altered competitive interactions. Nat. Clim. Change 2012, 3, 156-159.

170. Connell, S.; Russell, B. The direct effects of increasing $\mathrm{CO}_{2}$ and temperature on non-calcifying organisms: increasing the potential for phase shifts in kelp forests. Proc. R. Soc. Biol. Sci. B 2010, 277, 1409-1415.

171. de Mazancourt, C.; Johnson, E.; Barraclough, T.G. Biodiversity inhibits species' evolutionary responses to changing environments. Ecol. Lett. 2008, 11, 380-388.

172. Johansson, J. Evolutionary responses to climate changes: how does competition affect adaptation? Evolution 2008, 62, 421-435.

173. Fabricius, K.E.; Langdon, C.; Uthicke, S.; Humphrey, C.; Noonan, S.; De'ath, G.; Okazaki, R.; Muehllehner, N.; Glas, M.S.; Lough, J.M. Losers and winners in coral reefs acclimatized to elevated carbon dioxide concentrations. Nat. Clim. Change 2011, 1, 165-169.

174. Dunn, R.R.; Harris, N.C.; Colwell, R.K.; Koh, L.P.; Sodhi, N.S. The sixth mass coextinction: Are most endangered species parasites and mutualists? Proc. R. Soc. Biol. Sci. B 2009, 276, 3037-3045.

175. Stenseth, N.C.; Smith, J.M. Coevolution in ecosystems: Red queen evolution or stasis? Evolution 1984, 38, 870-880.

176. Lawrence, D.; Fiegna, F.; Behrends, V.; Bundy, J.G.; Phillimore, A.B.; Bell, T.; Barraclough, T.G. Species interactions alter evolutionary responses to a novel environment. PLoS Biol. 2012, 10, doi:10.1371/journal.pbio.1001330.

177. Chesson, P. A need for niches? Trends Ecol. Evol. 1991, 6, 26-28.

178. Byrnes, J.E.; Gamfeldt, L.; Isbell, F.; Lefcheck, J.S.; Griffin, J.N.; Hector, A.; Cardinale, B.J.; Hooper, D.U.; Dee, L.E.; Emmett Duffy, J. Investigating the relationship between biodiversity and ecosystem multifunctionality: Challenges and solutions. Meth. Ecol. Evol. 2014, 5, 111-124.

179. Pereira, H.M.; Leadley, P.W.; Proença, V.; Alkemade, R.; Scharlemann, J.P.W.; Fernandez-Manjarrés, J.F.; Araújo, M.B.; Balvanera, P.; Biggs, R.; Cheung, W.W.L.; et al. Scenarios for global biodiversity in the 21 st century. Science 2010, 330, 1496-1501.

180. Burrows, M.T.; Schoeman, D.S.; Richardson, A.J.; Molinos, J.G.; Hoffmann, A.; Buckley, L.B.; Moore, P.J.; Brown, C.J.; Bruno, J.F.; Duarte, C.M.; et al. Geographical limits to species-range shifts are suggested by climate velocity. Nature 2014, 507, 492-495.

181. Pespeni, M.H.; Chan, F.; Menge, B.A.; Palumbi, S.R. Signs of adaptation to local pH conditions across an environmental mosaic in the California current ecosystem. Integr. Comp. Biol. 2013, 53, 857-870.

182. Ricevuto, E.; Kroeker, K.J.; Ferrigno, F.; Micheli, F.; Gambi, M.C. Spatio-temporal variability of polychaete colonization at $\mathrm{CO}_{2}$ vents indicates high tolerance to ocean acidification. Mar. Biol. 2014, 161, 2909-2919.

183. Hughes, T.P.; Baird, A.H.; Bellwood, D.R.; Card, M.; Connolly, S.R.; Folke, C.; Grosberg, R.; Hoegh-Guldberg, O.; Jackson, J.B.C.; Kleypas, J.; et al. Climate change, human impacts, and the resilience of coral reefs. Science 2003, 301, 929-933.

184. Bellantuono, A.J.; Hoegh-Guldberg, O.; Rodriguez-Lanetty, M. Resistance to thermal stress in corals without changes in symbiont composition. Proc. R. Soc. Biol. Sci. B 2012, 279, 1100-1107.

185. Barshis, D.; Ladner, J.; Oliver, T.; Palumbi, S.R. Lineage specific transcriptional profiles of Symbiodinium spp. unaltered by heat stress in a coral host. Mol. Biol. Evol. 2014, 31, 1343-1352. 
186. Benton, M.J. The Red Queen and the Court Jester: Species diversity and the role of biotic and abiotic factors through time. Science 2009, 323, 728-732.

187. Drake, J.M.; Lodge, D.M. Hull fouling is a risk factor for intercontinental species exchange in aquatic ecosystems. Aq. Inv. 2007, 2, 121-131.

188. Walther, G.-R.; Roques, A.; Hulme, P.E.; Sykes, M.T.; Pysek, P.; Kühn, I.; Zobel, M.; Bacher, S.; Botta-Dukát, Z.; Bugmann, H.; et al. Alien species in a warmer world: Risks and opportunities. Trends Ecol. Evol. 2009, 24, 686-693.

189. Bianchi, C.N. Biodiversity issues for the forthcoming tropical Mediterranean Sea. Hydrobiologia 2007, 580, 7-21.

190. Irwin, A.J.; Finkel, Z.V.; Schofield, O.M.E.; Falkowski, P.G. Scaling-up from nutrient physiology to the size-structure of phytoplankton communities. J. Plankton Res. 2006, 28, 459-471.

191. Levine, J.M.; Vilà, M.; Antonio, C.M.D.; Dukes, J.S.; Grigulis, K.; Lavorel, S. Mechanisms underlying the impacts of exotic plant invasions. Proc. R. Soc. Biol. Sci. B 2003, 270, 775-781.

192. Schluter, D. Experimental evidence that competition promotes divergence in adaptive radiation. Science 1994, 266, 798-801.

193. Halpern, B.S.; Selkoe, K.A.; Micheli, F.; Kappel, C.V. Evaluating and ranking the vulnerability of global marine ecosystems to anthropogenic threats. Conserv. Biol. 2007, 21, 1301-1315.

194. Barton, A.D.; Pershing, A.J.; Litchman, E.; Record, N.R.; Edwards, K.F.; Finkel, Z.V.; Kiørboe, T.; Ward, B.A. The biogeography of marine plankton traits. Ecol. Lett. 2013, 16, 522-534.

195. Reusch, T.B.H.; Boyd, P.W. Experimental evolution meets marine phytoplankton. Evolution 2013, 67, 1849-1859.

196. Russell, B.D.; Wernberg, T.; Mieszkowska, N.; Widdicombe, S.; Hall-Spencer, J.; Connell, S. Predicting ecosystem shifts requires new approaches that integrate the effects of climate change across entire systems. Biol. Lett. 2012, 8, 164-166.

197. Hendriks, I.E.; Duarte, C.M. Ocean acidification: Separating evidence from judgment—A reply to Dupont et al. Estuar. Coast. Shelf Sci. 2010, 89, 186-190.

198. Gaylord, B.; Hill, T.M.; Sanford, E.; Lenz, E.A.; Jacobs, L.A.; Sato, K.N.; Russell, A.D.; Hettinger, A. Functional impacts of ocean acidification in an ecologically critical foundation species. J. Exp. Biol. 2011, 214, 2586-2594.

199. Vihtakari, M.; Hendriks, I.; Holding, J.; Renaud, P.; Duarte, C.; Havenhand, J. Effects of ocean acidification and warming on sperm activity and early life stages of the Mediterranean mussel (Mytilus galloprovincialis). Water 2013, 5, 1890-1915.

200. Van Valen, L. A new evolutionary law. Evol. Theor. 1973, 1, 1-30.

(C) 2014 by the authors; licensee MDPI, Basel, Switzerland. This article is an open access article distributed under the terms and conditions of the Creative Commons Attribution license (http://creativecommons.org/licenses/by/4.0/). 